\title{
Kernos
}

Revue internationale et pluridisciplinaire de religion grecque antique

32 | 2019

Varia

\section{The Cult of Aratus at Sicyon (Plutarch, Aratus, 53)}

\section{Dennis D. Hughes}

\section{CpenEdition \\ Journals}

\section{Electronic version}

URL: https://journals.openedition.org/kernos/3126

DOI: $10.4000 /$ kernos. 3126

ISSN: 2034-7871

\section{Publisher}

Centre international d'étude de la religion grecque antique

\section{Printed version}

Date of publication: 1 December 2019

Number of pages: 119-150

ISBN: 978-2-87562-229-7

ISSN: 0776-3824

\section{Electronic reference}

Dennis D. Hughes, "The Cult of Aratus at Sicyon (Plutarch, Aratus, 53)", Kernos [Online], 32 | 2019,

Online since 01 October 2021, connection on 01 February 2022. URL: http://journals.openedition.org/ kernos/3126 ; DOl: https://doi.org/10.4000/kernos.3126

This text was automatically generated on 1 February 2022.

Kernos 


\title{
The Cult of Aratus at Sicyon (Plutarch, Aratus, 53)
}

\author{
Dennis D. Hughes
}

I delivered a version of this paper at the conference "Les cultes aux rois et aux héros dans l'antiquité. Continuités et changements à l'époque hellénistique", held at the University of Lausanne (10 - 12 May, 2017). I thank the organizers for their hard work and warm hospitality and them and the other participants for insightful comments and good conversation. I am also grateful to the two anonymous reviewers from Kernos for valuable criticism and references and to the American School of Classical Studies at Athens for the use of the excellent Blegen Library. For the sake of convenience I cite inscriptions primarily with reference to the collections of Sokolowski (see Abbreviations, below); but where deemed desirable I add references to other editions, both prior and subsequent. I began my word-searches with the inadequate and sometimes inaccurate indices in Sokolowski's works but then supplemented them using the Packard Humanities Institute site (http://epigraphy.packhum.org). For searches in literature I have relied on the on-line Thesaurus Linguae Graecae (http://stephanus.tlg.uci.edu). In neither case - much less in the case of modern scholarship - do I make a claim of completeness.

\section{Introduction}

In $213 \mathrm{BC}$ Aratus son of Cleinias fell ill and died at Aigion (Aegium), the seat of the Achaean Confederacy on the north coast of the Peloponnesus. It was rumored that he had been poisoned by Philip V of Macedon. ${ }^{1}$ After his death his remains were taken to his native Sicyon, where he was buried "as savior and founder" in the agora. Plutarch gives the fullest - if not necessarily the most trustworthy - account of the events following the death of the prominent general and statesman: ${ }^{2}$

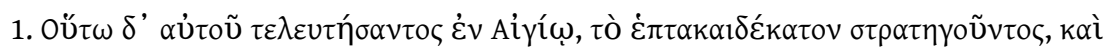

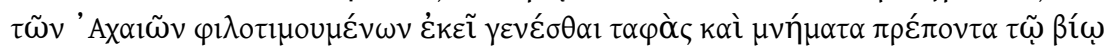

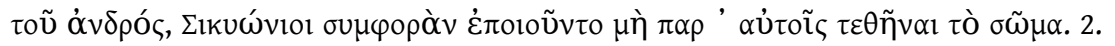

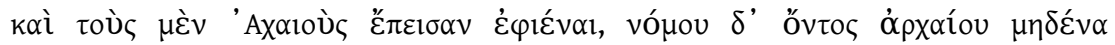

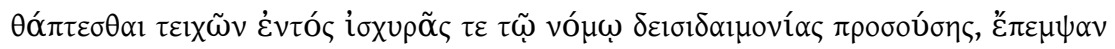




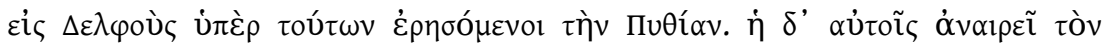

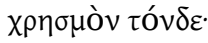

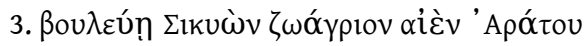

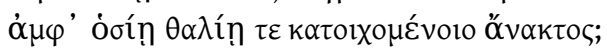

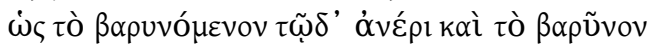

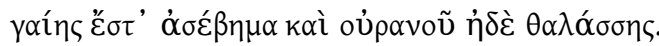

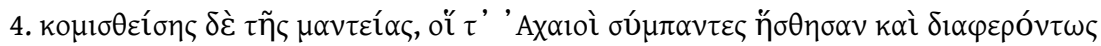

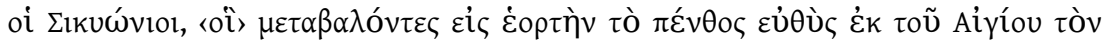

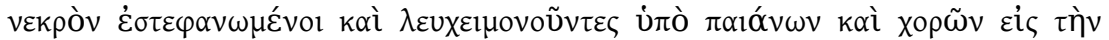

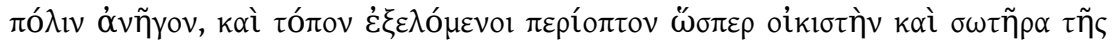

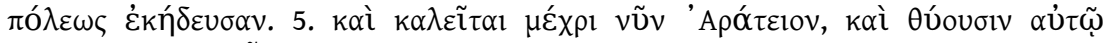

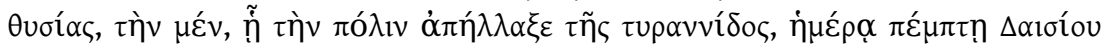

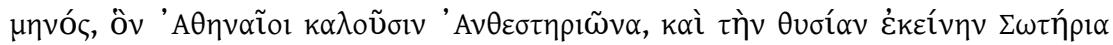

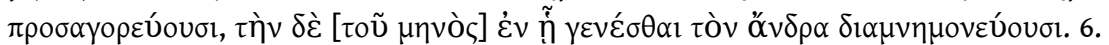

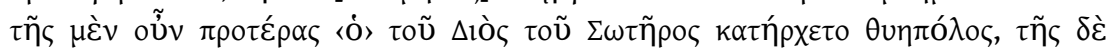

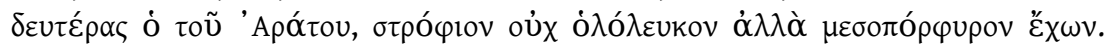

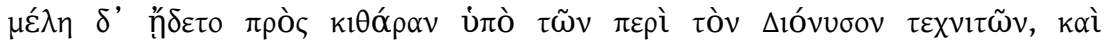

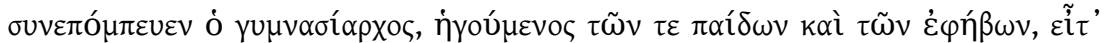

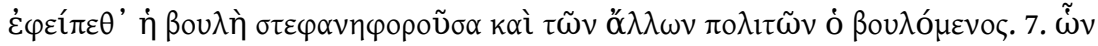

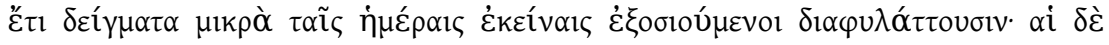

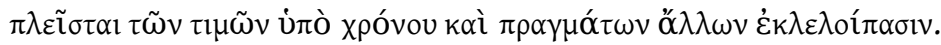

1. And when he had died in this way in Aigion, while holding the generalship for the seventeenth time, and the Achaeans desired the honor of having his burial take place there and memorials befitting the man's life erected, the Sicyonians thought it a misfortune for the body not to be buried among them. 2. And they persuaded the Achaeans to release it, but, there being an ancient law that no one be buried within the walls and a powerful superstition attaching to the law, they sent to Delphi to question the Pythia about these matters. And she gives them the following response:

3. Will you deliberate endlessly, Sicyon, on a thank-offering for Aratus, in rite and celebration of your departed lord?

Since [?] what is burdened by [?] this man and what burdens

of earth is profanation and of sky and sea.

4. And when the response had been brought back, the Achaeans as a whole were pleased, and especially the Sicyonians, who, transforming their mourning into festivity, immediately set about bringing the body back from Aigion to the city, wreathed and wearing white clothing, accompanied by paeans and choruses. And having chosen a prominent place they buried him as founder and savior of the city. 5. And it is called to this day the Arateion, and they perform sacrifices to him, one on the day on which he liberated the city from the tyranny, the fifth day of the month Daisios, which Athenians call Anthesterion, and that sacrifice they call Soteria, but the other they perform on the day on which they record that the man was born. 6 . So the priest of Zeus Soter would preside over the former sacrifice, but over the latter the priest of Aratus, wearing a headband not completely white but purple-striped. And songs would be sung to the accompaniment of the kithara by the Dionysiac Artists, and the gymnasiarch would also take part in the procession, at the head of the boys and the ephebes; next would follow the boule, crowned with wreaths, and any of the other citizens who wished. 7. And on those days in pious devotion they still preserve small traces of these rites; but the majority of the honors have fallen into disuse, from the passage of time and other factors.

Plutarch's account of the aftermath of Aratus's death is for several reasons suspect: the obscurely-worded oracular response quoted by Plutarch would not appear to be a genuine reply of the Pythia; the "ancient law" forbidding burial within the city of Sicyon may never have existed; and the sequence of events as Plutarch relates them - 
the dispute with the Achaeans over the body, the dispatch of someone to Delphi to consult the oracle and his return to Aigion, the transport of the body from Aigion to Sicyon, and the funeral - would seem to require an implausibly long period of time between the death of Aratus and his interment. Plutarch's description of the festival, on the other hand, rings true, and its close similarity to Hellenistic inscriptions concerned with religious festivals suggests that it derives - not directly, I will argue, but indirectly through an intermediate source - from an inscribed decree, which provided for Aratus's burial in the city and the creation of an annual festival in his honor. ${ }^{3}$ The details given by Plutarch - the dress of the priest, the role of the Dionysiac Technitai, and the participation of the gymnasiarch, along with boys and adolescents, and of city officials and other citizens - all have counterparts in inscriptions, particularly those giving instructions for the conduct and ordering of processions. Most of the vocabulary, with a few notable anomalies, ${ }^{4}$ is familiar from inscriptions as well. These inscriptions may in turn be used to flesh out Plutarch's somewhat skeletal account and to offer a tentative reconstruction of Aratus's annual festival.

\section{The retrieval of Aratus's body}

\section{The oracle and transport of the body}

3 According to Plutarch, after the death of Aratus the Sicyonians were able to persuade the Achaeans, who themselves wished to bury Aratus in Aigion, to release the body for burial in Sicyon. The Sicyonians also wanted to be able to bury him within their walls, but, faced with an ancient prohibition against burial inside of the city, they consulted the oracle at Delphi, and, interpreting the Pythia's response as granting permission to do as they wished, they joyously transported Aratus's body to Sicyon and buried him in a "prominent place", which we learn from Pausanias was in the agora, in front of the former house of the tyrant Cleon, converted by Pausanias's time into a temenos of the Roman emperors. ${ }^{5}$ This story has been repeated and apparently accepted as factual by scholars, ${ }^{6}$ but much of the account does not hold up well under close scrutiny. If the silence of Polybius and Pausanias about the Sicyonian law and the consultation of Delphi is not decisive, ${ }^{7}$ the oracle itself, a cryptic response in hexameters - the announcement of which one would think would have been met more with perplexity than joy - surely should be regarded as inauthentic, especially since, or so at least we are told by ancient sources, Delphi had long ceased issuing oracles in verse by the time under consideration here. ${ }^{8}$ Still, it could be argued that the consultation of Delphi actually took place, with a fictitious oracle being fabricated at some time after the fact. But there is another serious problem with Plutarch's account. If we grant, for the sake of argument, that "the Sicyonians" are meant to be Sicyonians already present in Aigion, rather than a delegation that set out from Sicyon to Aigion upon receiving word of Aratus's death, still we are asked to imagine that, after a dispute with the Achaeans has been resolved, someone is dispatched to Delphi, locates a ship to take him across the gulf to Itea, makes the steep climb from there to the sanctuary of Apollo, where he must wait his turn, possibly for days, to consult the oracle, and then makes his way back to Aigion, oracular response in hand, all while the body of Aratus awaits burial and begins to decompose. Only when the messenger has returned from Delphi can the transport of the body to Sicyon, by land or by sea, begin. The distances are not great, but the conditions of ancient travel were far from ideal, and even the hike from Itea to 
Delphi could occupy the better part of a day. The sequence of events as Plutarch narrates them could easily take a week or longer, perhaps much longer, ${ }^{9}$ before Aratus's remains could be laid to rest in his native city. Certainly burial within three (i.e. our two) days, the customary period between death and funeral, ${ }^{10}$ would be out of the question.

4 Another possibility suggests itself, which at least would remove the difficulty of the improbable gap between death and burial in Plutarch's account. Three decades later, Philopoemen, like Aratus rumored to have been poisoned, died in prison in Messene. ${ }^{11}$ But in this instance - again Plutarch is one of the sources - his body was cremated before his ashes were ceremoniously transported in an urn, carried by the young Polybius, from Messene to Megalopolis. Of his burial Plutarch writes only that "he was

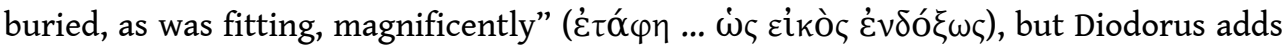

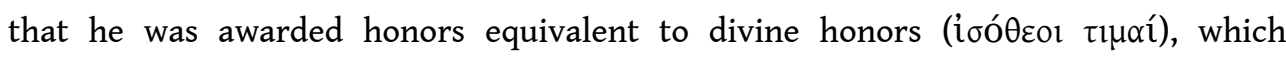
included the annual sacrifice of an ox and encomia and hymns sung by young men. Some of this is confirmed by a badly mutilated inscription, where we learn further that the sacrifice will take place on the day of the festival of Zeus Soter, when athletic and equestrian contests are held, and that a number of bronze statues of Philopoemen will be set up around the city. Philopoemen will also have an altar and a monument in the

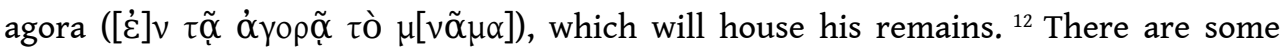
notable similarities between the cults of Aratus and Philopoemen; but for information about the transport of the remains and the burial we are on much surer historical ground in the case of the latter. ${ }^{13}$

But to return to Aratus: might his body, whatever delay may have occurred before he could be taken to Sicyon, also have been cremated, in Aigion? This would seem to have been practical under the circumstances - at least under the circumstances as Plutarch relates them. But here we find ourselves having to rewrite the text of Plutarch, who states clearly that the Sicyonians retrieved Aratus's corpse, which may well be one of few reliable details in the whole story. ${ }^{14}$ There is a stark inconsistency between what Plutarch reports about the transport and inhumation of Aratus's body and the time it would have taken to travel to Delphi beforehand to secure permission for the inhumation. Further doubt is cast on the account by Plutarch's assertion that there was an ancient Sicyonian law forbidding intramural burial, a law that occasioned the consultation of the oracle in the first place.

\section{The "ancient law"}

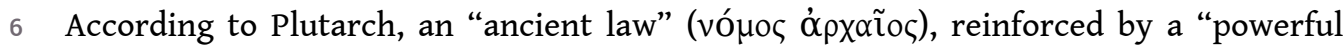

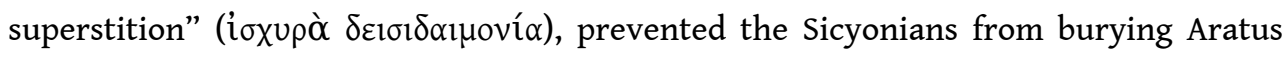
within the walls of the city. ${ }^{15}$ Of course it was customary for the Greeks to bury their dead outside of their cities' walls, beginning along the roads leading out of the city gates. ${ }^{16}$ If this is all that is meant by Sicyon's ancient law, then its existence is unremarkable enough. But it had also been widespread practice for centuries to bury the "heroized" dead, the founders of colonies particularly but also those who were

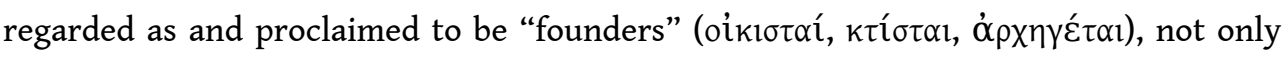
within the walls but in the heart of the city, in the agora itself. As a scholiast on Pindar puts it, "founders would be buried in the middle of the cities out of custom", with apparent reference to ancient Greece generally. ${ }^{17}$ Still, it is implicit in Plutarch's 
account that Sicyon was exceptional in this regard: if the story is to make any sense, the ancient law must have strictly denied intramural burial to everyone, even to Sicyon's most prominent benefactors. But there is substantial evidence that this was not the case. In the sixth century, Herodotus tells us, the Sicyonian tyrant Cleisthenes, at war with Argos, desired to oust the Argive Adrastus and his worship from Sicyon. He consults the Delphic oracle, and, although the reply he receives is not at all encouraging, he contrives to bring the remains of Melanippus from Thebes, to have them reinterred in the prytaneion, and to replace the old cult of Adrastus with his. Now we may be far from reliable history in this case also, but as Herodotus notes in passing that "there was and is a heroön of Adrastus son of Talaus in the agora itself of the Sicyonians" it appears that in the fifth century there was a monument in the marketplace thought to mark the burial place of Adrastus; presumably the Sicyionians also believed that the remains of Melanippus still lay beneath their prytaneion. ${ }^{18}$ Then from the fourth century we have a contemporary and apparently reliable reference to another burial in the Sicyonian agora. In 366/5 the popular leader and "tyrant" Euphron was assassinated by enemies in Thebes; the Thebans determined that he got what he deserved, reports Xenophon: "His fellow citizens, however, deeming him a good man, having brought him home buried him in the agora and worship him as archègetēs of the city". ${ }^{19}$ And finally, from the realm of myth, an epigram, inscribed on a bronze plaque found near Sicyon and dated to the fourth century BC, proclaims that Iphinoë, one of the daughters of Proetus, having been cured of her madness and died,

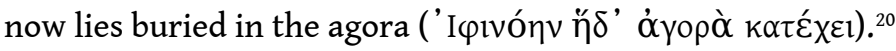

7 Although attempts have been made to explain the discrepancy between Plutarch's assertion that a law prohibiting intramural burial existed and the considerable evidence to the contrary, ${ }^{21}$ in my opinion the simplest explanation is that there never was such a law at Sicyon..$^{22}$ Indeed, were it not for Plutarch's singular mention of the law, scholars would justifiably speak of a longstanding tradition of burial in the agora of Sicyon, which culminated in the funeral of Aratus in $213 \mathrm{BC}$. The obstacles encountered by the Sicyonians add a nice, if implausible, peripety to an otherwise straightforward narrative, but in the end it is best to follow the brief and unembellished account of Pausanias - "And, having transported him from Aigion (for this is where his fate had overtaken him) to Sicyon, they bury him, and the heroön is still called the Arateion" conceding that the precise details can no longer be recovered. ${ }^{23}$

\section{The festival of Aratus and some epigraphic parallels}

\section{Plutarch's use of inscriptions}

8 That Plutarch made fairly extensive use of inscriptions and other documentary evidence in his writings is well known. In some cases he has looked at inscriptions himself, if only to confirm the presence of a name or determine the identity of a statue by reading the epigram on its base. But although he certainly recognized the historical value of epigraphic evidence he does not seem to have been the sort to get down on his knees to copy out inscriptions by hand; in the majority of cases he knew the texts of inscriptions from literary sources. ${ }^{24}$ Only rarely is there a clear indication that he has seen an inscription himself, as when he quotes an epigram from the temple of Artemis Proseoa near Artemisium and mentions the effect of rubbing the surface of the stone 
with his hand. ${ }^{25}$ But there is no such indication, when Plutarch quotes a six-line elegy inscribed on the base of a statue of Aratus erected by his fellow Sicyonian exiles, that he had seen the statue or the poem in person; in this case he may have drawn on Aratus's own Memoirs. ${ }^{26}$ In fact, I find no conclusive evidence that Plutarch had ever set foot in Sicyon at all. ${ }^{27}$

If Plutarch had before him a text of a Sicyonian decree, he chose not to reproduce it verbatim but rather to represent the festival as an event regularly enacted in the past, which required conversion of the presumed third-person imperatives of the original

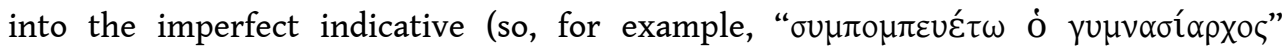

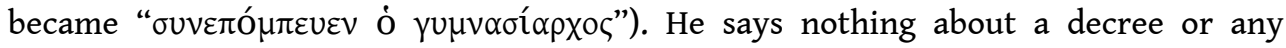
literary source. Much of this may be unusual for Plutarch, but comparison with two similar cases, one from the Parallel Lives and one from the Moralia, is instructive and may shed some light on what he is doing here. At the end of the Timoleon Plutarch recounts the death of the Corinthian Timoleon in Syracuse and his burial there at public expense. Both Diodorus and Plutarch, clearly relying on the same (unnamed) source (i.e. Timaeus), ${ }^{28}$ quote the beginning of a decree read aloud by a herald at the funeral, proclaiming that Timoleon will henceforth be honored with contests, musical, equestrian, and athletic. Diodorus gives what seem to be the exact words of the decree, but Plutarch edits the text somewhat, not only atticizing Doric forms but also converting the infinitives of the original ( $\theta \alpha \dot{\alpha} \tau \tau \varepsilon ı v, \tau \imath \mu \tilde{\alpha} \sigma \theta \alpha \mathrm{l}$ ) into the present and aorist indicative ( $\theta \dot{\alpha} \pi \tau \varepsilon l, \dot{\varepsilon} \tau \hat{\imath} \mu \eta \sigma \varepsilon)$. Plutarch then goes on to give details not found in Diodorus, that the Syracusans buried Timoleon in the agora and eventually added stoas and a gymnasium, which they named the Timoleonteion. ${ }^{29}$ Thus we have an instance of Plutarch's use of a decree, taken from an unacknowledged source and slightly altered, as the basis for an account of the establishment of a hero cult at the end one of his Lives. Then in the Roman and Greek Questions Plutarch provides information about Argive funeral practices, which appears to derive from inscribed funerary regulations known to Plutarch from Socrates of Argos, the author of a guide to the Argolid and a book on

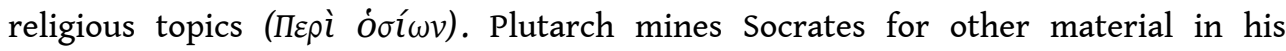
Questions, most often without acknowledgement. ${ }^{30}$ Is it possible that Plutarch made use of a similar collector of Sicyonian lore in writing his account of the festival of Aratus? I shall return to this question below ( $(4)$, after an examination of the content and language of the passage.

\section{The dress of the priest ${ }^{31}$}

10 The dress of priests, priestesses, and other religious officials is sometimes specified in inscribed texts. In the third century BC at Pergamum, the winner of a priesthood (of a deity whose name is not preserved) will wear a white chlamys and a wreath of olive sprig decorated with a crimson ribbon. On Cos in the first century BC, the purchaser of the priesthood of Zeus Alseios will wear a purple chiton, an olive wreath with some sort

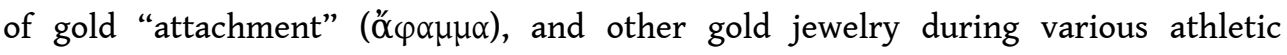
contests; and the Coan priest of Nike is to participate in a yearly procession and sacrifice wearing a purple chiton, gold rings, and an olive wreath; this will also be his attire whenever he is in Nike's sanctuary and at all other sacrifices. ${ }^{32}$ In Plutarch, the priest of Aratus wears a strophion, a headband or crown made of twisted fabric, presumably wool, though a strophiskos of gold is also attested. The word is found 
occasionally in inscriptions: the buyer of an eponymia from an association of Sarapiasts on Thasos will wear a white strophion, and during the Andanian mysteries each member of the "Ten" will wear a purple one. Most notably, the strophion, usually topped by a wreath, was worn by hierophants and daduchs at Eleusis: in fact, Plutarch's only other use of the word occurs in an anecdote about Callias, a daduch, who appeared on the battlefield at Marathon sporting the insignia of his office..$^{33}$

11 At Sicyon the strophion worn by the priest of Aratus was "not all white but purple-

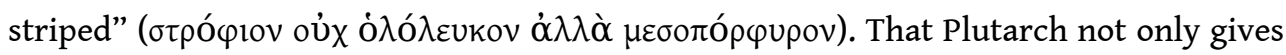
the color of the headband but also states what color it was not is curious, and it seems possible that he has condensed a longer section on the priest's clothing. So in the cult of Nike on Cos the priest will wear a purple chiton, gold rings, and a wreath when performing his official duties, but otherwise, over the course of his life, he will wear

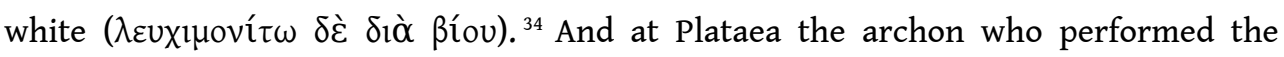
annual rites honoring the Greeks who fell in battle against the Persians would don a purple chiton for the occasion but at other times was required to wear white clothing only ${ }^{35}$ Similarly, the priest of Aratus may have worn a white strophion normally but a special purple and white one once a year on the occasion of the hero's festival.

It should be noted that the two adjectives used by Plutarch here, ò $\lambda^{\prime} \lambda \varepsilon v \kappa o \varsigma$ and

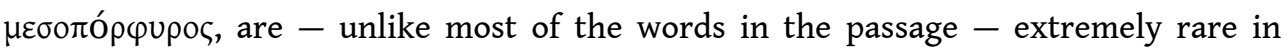
extant inscriptions. For the latter I find only one instance, of a chlamys listed in a fragmentary inventory of votives from Delos (first century BC). The former word, ò ó$_{\varepsilon v \kappa \kappa}$, seems to be unattested, though it may plausibly be restored in an inscription from Iasos, in which the virgin priestess of Queen "Aphrodite" Laodice III, selected annually, is instructed to wear a strophion during her "excursions": [ $\dot{\varepsilon} v \delta \grave{\varepsilon}] \tau \alpha \tilde{c} \varsigma$

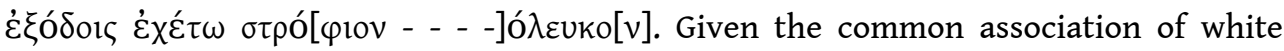
clothing with purity - not to mention regulations mandating simplicity in women's

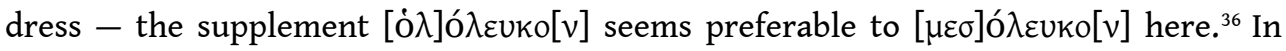
any case it should also be noted that, in addition to their rarity in, and in one case possible absence from, inscriptions, neither adjective appears elsewhere in the writings of Plutarch.

While I am on the subject of dress I am tempted to suggest the possibility that the inscribed decree that founded the festival of Aratus was also Plutarch's source for some details of his description of the Sicyonians who escorted Aratus's body into the city. These, Plutarch writes, conveyed the corpse to Sicyon "wreathed and wearing white

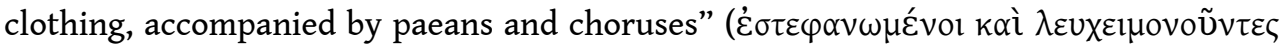

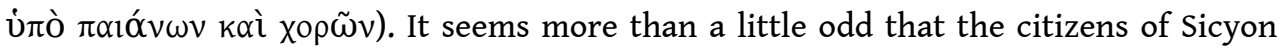
would have been able to orchestrate such an impressive procession, including special clothing and musicians and troupes of dancers, at a moment's notice. And Plutarch's vocabulary here is certainly reminiscent of language found in religious inscriptions. So at Corope consultants of the oracle of Apollo would be dressed in bright white clothing

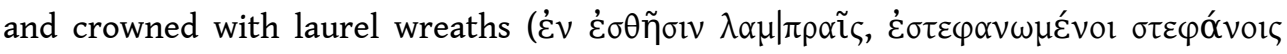
$\delta \alpha \varphi v i$ vors); and at Stratoniceia the paidonomos would conduct a daily procession

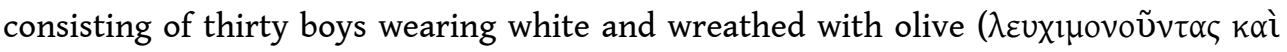

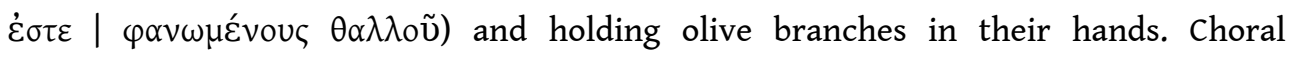
performances and the singing of paeans at festivals are also not uncommon. ${ }^{37}$ But admittedly such details appear in literary descriptions of worshippers as well (with both the literary descriptions and the inscriptions, of course, reflecting a common 
reality). ${ }^{38}$ Plutarch himself represents the mourners at Timoleon's funeral as "all

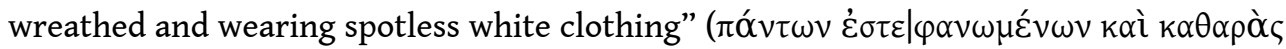

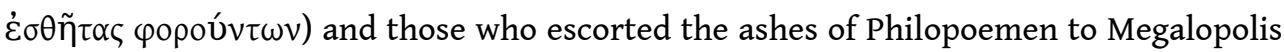
as wearing wreaths. Indeed, in this section of the Aratus we may detect the hand of Plutarch at work, especially in the conceit that the Sicyonians had "transformed their mourning into festivity", for we find similar expressions at the end of his lives of Timoleon and Philopoemen: the appearance of the many men and women present at Timoleon's funeral was "appropriate to a festival", and those accompanying Philopoemen's ashes are said to have "combined a sort of victory parade with the obsequies" ${ }^{39}$ Thus, whatever the origin of his description of the Sicyonians at Aratus's funeral (material from an inscription skillfully transferred here, from some historical source, or from his own imagination?), these parallels suggest that the motif of the "festive funeral" is likely to be Plutarch's own contribution to the narrative.

\section{Music and the Artists of Dionysus}

"And songs would be sung", Plutarch continues, "to the accompaniment of the kithara by the Dionysiac Artists". ${ }^{40}$ From the first half of the third century BC, associations, or

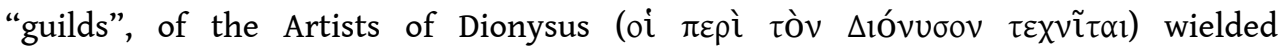
considerable influence in the Greek-speaking world. These associations (koina, synodoi) provided theatrical and musical performers for competitions and festivals in Greek cities and were capable of securing in return various protections and privileges for their members, acting in the process much like city-states themselves. Their membership included tragic and comic actors, poets, choral performers, and a variety of singers and musicians, including kitharodes and kithara players, whom we encounter singing and playing during the festival of Aratus. At Sicyon the performers will have belonged to the Isthmian (or Isthmian-Nemean) koinon (there were also associations in Athens, Asia Minor, and Egypt). ${ }^{41}$ Most of what we know about these associations comes from inscriptions, though they also make occasional appearances in literature, including elsewhere in the work of Plutarch. ${ }^{42}$

Music and singing, of course, were common elements of Greek festivals, and the kithara a particularly popular instrument. Often the musicians would also be included in the processions. In Eretria, a festival of Artemis featured musical contests involving rhapsodes, aulos players, parodic performers, kitharodes, and kithara players, who would all march afterward in a large parade. At Magnesia-on-the-Maeander various musicians took part in a procession for Zeus Sosipolis, including a kitharistēs. At the Coan festival of Nike kithara players would lead boys in playing a spondeion on the kithara, "just as they do in the other processions". ${ }^{43}$ At Andania aulos players would march in the parade held at the time of the mysteries of Demeter. ${ }^{44}$ In a few instances we hear of the participation of Artists of Dionysus in processions, a role they played in Sicyon during the festival of Aratus. ${ }^{45}$

\section{The gymnasiarch and his charges}

16 After the priest and the musicians, writes Plutarch, "the gymnasiarch would also take

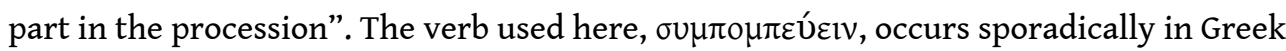
literature (the earliest instances are in Aeschines, Anaximenes of Lampsacus, and Timaeus), although it does not occur elsewhere in Plutarch. ${ }^{46}$ But it is found frequently 
(over twenty-five times) in a variety of inscribed texts concerned with processions, the majority of them dating from the second half of the fourth century $\mathrm{BC}$ to the early years of our era, so, roughly, the Hellenistic period, which might be called the "heyday" of the large Greek civic procession. ${ }^{47}$ All of these processions involved the "escorting" of animals to be sacrificed..$^{48}$ For example, in Magnesia the stephanepphoros, along with the priest of Zeus and the priestess of Artemis Leukophryene, is to lead the procession

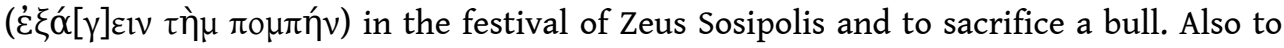

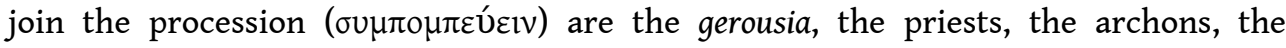
ephebes, young men, and boys, and victors in the Leukophryena and other Panhellenic, "crown-awarding" games; then, after the sacrifice, the meat of the bull will be

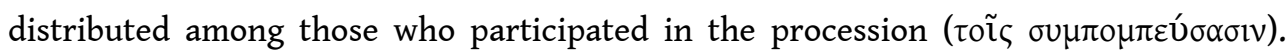
Similarly, if less extravagantly, at the festival of the Ptoia in Oropos the archon, polemarchs, and secretary are intructed to "send" an ox ( $\pi \varepsilon \dot{\varepsilon} \mu \pi \varepsilon i v$ ßoṽv) from the city and themselves to join in accompanying it ( $\alpha \dot{u} \tau o u ̀ \varsigma ~ \sigma u \mu \pi о \mu \pi \varepsilon v$ viv) to the sanctuary of Apollo Ptoios ${ }^{49}$ Lists such as these are a recognizable feature of Hellenistic inscriptions in which instructions for the conduct and ordering of processions are given.

The gymnasiarch was, in the Hellenistic period, an annually elected official charged with the administration of the gymnasium, the athletic and sometimes intellectual training ground of male youths..$^{50}$ Among his many responsibilities was to take part in the organization of festivals involving athletic contests, sacrifices, and processions. At the festival of Aratus the gymnasiarch is said to have marched "at the head of the boys and the ephebes"; and there are many epigraphic parallels for the participation of boys and ephebes in parades, with or without (or at least without mention of) a gymnasiarch. For example, in mid-second century BC Antioch-on-the-Pyramos a decree mandates that a procession be conducted ( $\pi \varepsilon \mu \varphi \theta \tilde{\eta} v \alpha l \pi o \mu \pi \eta v)$ by the demmiourgos and members of the prytany and that two heifers with gilded horns be sacrificed to Athena and Homonoia; others are also to join the procession ( $\sigma u \mu \pi о \mu \pi \varepsilon \tilde{v} \sigma \alpha 1)$ : the priests,

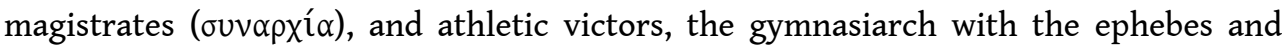
young men, and the paidonomos with the boys. Then at the end of the same century, in the cult of the heroized Aleximachus in Aigiale on Amorgos, the prytany-members, the

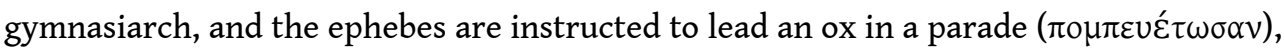
followed by all the younger males, whom the gymnasiarch is to induce to participate "in whatever way he is able". Later on in the inscription (which I shall have occasion to cite often in the remainder of this paper) we learn that the gymnasiarch will also be responsible for organizing a lampas, a "torch race" of men and boys, and for compelling the younger boys to run..$^{51}$

\section{The members of the boule}

After the gymnasiarch, boys, and ephebes, there followed the members of the boule, crowned with wreaths. ${ }^{52}$ In addition to priests, priestesses, and other cult personnel, various other civic officials would take part in processions: archons, polemarchs, dèmarchoi, dēmiourgoi, members of the gerousia, "monarchs" on Cos, and, if contests of boys and adolescents were involved, gymnasiarchs, assistant gymnasiarchs (hypogymnasiarchoi), paidonomoi, and agōnothetai. ${ }^{33}$ But to judge from surviving inscriptions it would seem that the boule marched as a group only rarely. At Lindos in

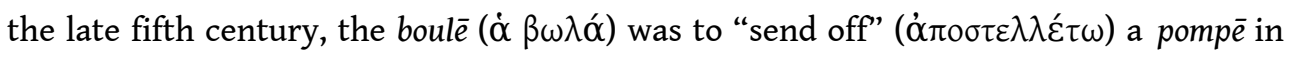


honor of Enyalios, consisting of hoplites and the animals to be sacrificed; and in an inscription from Actium (late third or early second century) the boule has been plausibly restored as the first contingent of a procession in the cult of Apollo. ${ }^{54}$ The evidence is scanty, and all from the second century BC, but it appears that more often it was a subset of the council, the members of the prytany serving in the month in question, who marched in Hellenistic processions. ${ }^{55}$ In Antioch the demmiourgos and prytaneis would march at the head of a long procession to the sanctuary of Athena Magarsia. At Delphi three separate monetary grants included provisions for parades from the halōs to the sanctuary of Apollo, where sacrifices were then performed, in the earliest case to Apollo Pythios alone and in the other two cases to Apollo, Leto, and Artemis. The cast of participants varies, but the members of the prytany appear in all three inscriptions, following the priests of Apollo and the archon in one case and, in the other two, the priests of Apollo and "the other gods". ${ }^{56}$ Then at the end of the century on Amorgos, the prytany-members were to march first in a procession conducting an ox to be sacrificed to the heroized Aleximachus. ${ }^{57}$

\section{The other citizens}

19 After the boule would follow "whoever wished of the other citizens" ( $\tau \tilde{\omega} v$ o $\alpha \lambda \omega \nu$

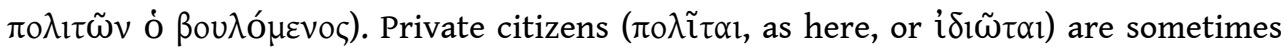
mentioned in inscriptions as participants in processions. At Delphi, in one of the three festivals mentioned above, a sacrifice to Apollo and a public banquet ( $\delta \alpha \mu \circ \theta$ ovví $\alpha$ ) were preceded by a procession consisting of the priests of Apollo, the archon, the members

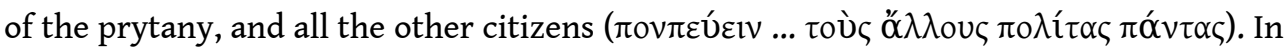
a procession held in Pergamum in honor of Attalus III, which included among others the gymnasiarch with the ephebes and neoi and the paidonomos with the boys, ended with the citizens (along with others residing in the city), who would then offer sacrifices, by tribe, for the king. Most interestingly, at the festival of Artemis in Eretria animal victims furnished by citizens would bring up the rear of the parade, "should any

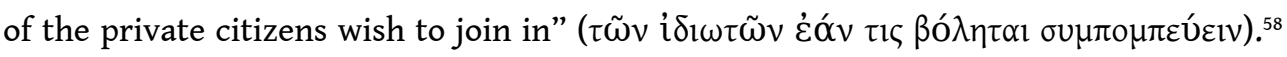
Finally, we have here a clear indication that an inscribed text rather than a written eyewitness account lies behind Plutarch's description of the procession, as surely no observer would speak of the citizen participants in this way, abstractly and in the

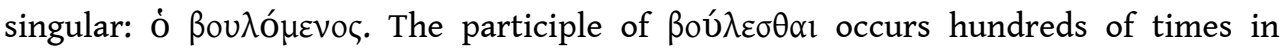
inscriptions, where, in a variety of contexts, permission is granted to perform certain acts, or to participate in certain activities, to any person who wishes; and in this and similar expressions ("if anyone wishes", "whoever wishes", etc.), as we would expect, we find the singular much more often than the plural..$^{59}$

\section{The Procession for Aratus in context}

The site of Hellenistic Sicyon lies some sixteen kilometers northwest of Old Corinth, on a plateau that rises from the present village of Kiato on the Corinthian Gulf. The city, which had been moved inland and refounded by Demetrius Poliorcetes in $303 \mathrm{BC}$, was laid out in a grid pattern with broad streets. ${ }^{60}$ Pausanias visited the site and saw numerous temples and other buildings, including a theater where a statue of Aratus was still standing, a gymnasium constructed by Aratus's father, a bouleuterion, and the 
tomb of Aratus, the Arateion. ${ }^{61}$ Among the structures whose remains are still visible today are the theater, a stadium, a monumental gymnasium, an unidentified Archaic temple (enlarged in the Hellenistic period), portions of a long stoa (early Hellenistic), and a large bouleutêrion, which, along with the gymnasium, may have played an important role in the procession held each year in honor of Aratus. But the Arateion itself has yet to be identified.

The participation of the members of the boule in the procession suggests the possibility that the marchers assembled at or near the bouleuterion in the agora and then set out from there. ${ }^{62}$ In inscriptions the bouleuterion is occasionally mentioned as the starting point of Hellenistic processions. ${ }^{63}$ At Antioch a large procession organized by the

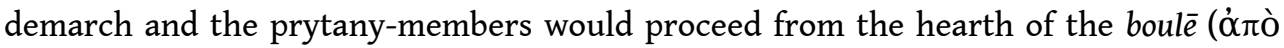

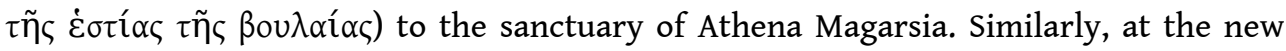
festival of the Eisiteria held in Magnesia for Artemis Leukophryene, a variety of officials - polemarchs, oikonomoi, the secretary of the boule, and others - were enjoined by a decree to gather dressed in distinctive clothing and crowns of laurel before the bouleuterion in the agora; from there evidently they would march to the sanctuary of the goddess. ${ }^{64}$ Furthermore, the agora had the advantage, as one inscribed text puts it explicitly, that the area "where the victims are sold" was often located there. ${ }^{65}$ The agora was thus a common and convenient place of departure for sacrificial processions. From the bouleuterion it is possible that the marchers proceeded to the nearby monument of Aratus to perform a sacrifice or other ritual at the grave.$^{66}$ From there, the fact that the gymnasiarch, ephebes, and boys were involved in the festival suggests that the procession would ultimately have made its way to the gymnasium, appropriately the gymnasium built by Aratus's father Cleinias, seen by Pausanias and plausibly identified with the imposing structure lying on two levels just west of the Hellenistic agora.${ }^{67}$ Here - again as in Aleximachus's cult on Amorgos - one or more victims will have been slaughtered and a lavish banquet held, with the sacrificial meat then distributed among the participants: the priest, the professional musicians, the gymnasiarch, boys, and ephebes, the bouleutai, and any other citizens who wished to join in the festivity, these last possibly being required to furnish animals at their own expense in order to do so. ${ }^{68}$

Finally, if the participation of the gymnasiarch and young men suggests a likely destination of the procession and a suitable location for the banquet that followed, their presence also suggests that the festival of Aratus may have involved games, athletic contests put on in the hero's honor. Such was the case in Syracuse in the cult of Timoleon and in Aigiale at the festival of Aleximachus, where the deceased Aleximachus would automatically be declared the winner of one of the events, the pankration. There may also have been musical contests in which the Technitai of Dionysus competed..$^{69}$ This combination of procession, sacrifices, and games - athletic but also sometimes equestrian or theatrical or musical - is found in many festivals of the Hellenistic period; and a decree concerned with the celebration of the Sminthia at Lindos underscores the close association of the three activities, in a concise

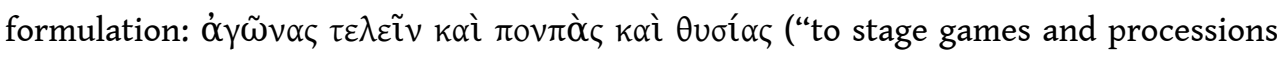
and sacrifices"). ${ }^{70}$ 


\section{Sources and Citation in the Aratus}

In writing the Aratus Plutarch drew extensively on Aratus's own Memoirs, to which he explicitly refers four times. ${ }^{71}$ He mentions his other major sources, Phylarchus and Polybius, once, together, for their testimony about Aratus's early, clandestine contacts with Antigonus Doson. Each of his remaining named sources Plutarch also cites only once: Myrsilus of Mytilene, in a short digression on famous look-alikes; Deinias, who is cited only for the name of the assassin of the tyrant Aristippus but whose Argolica was probably used for much of the surrounding account of Aratus's conflicts with Argos; and Polemon "the Periegete", whom Plutarch names as his source for the colorful history of a prominent Sicyonian painting..$^{72}$ Polemon seems also to have been Plutarch's source for other information in the Life, possibly including the description of the festival of Aratus.

Polemon of Ilium, the so-called Periegete, was a learned and well-traveled author who was active in the late third and early second centuries BC. ${ }^{73}$ Much of his writing was grounded in the material record, "the memorials and the things of fame" that he encountered in his travels: temples and other buildings, tombs, statues, paintings, votive offerings, and, notably, inscriptions. ${ }^{74}$ Not only did he copy and publish epigrams on tombstones and statue bases, but he also had the patience to transcribe decrees and even inventories of objects stored in temples and treasuries. Indeed, Polemon's passion

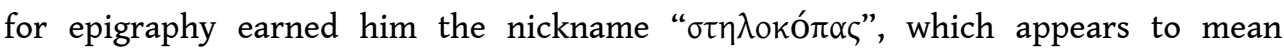
something like "glutton for stelae". ${ }^{75}$ It is also evident that Polemon spent considerable time in Sicyon. From Athenaeus we learn that, in addition to being called "the Samian" and "the Athenian", he was known to some as "the Sicyonian". ${ }^{76} \mathrm{He}$ is said to have written two books on Sicyonian painting, and as he refers to Sicyon elsewhere it is likely that he wrote one or more other books, perhaps including a periegesis, about the city. ${ }^{77}$

Plutarch cites Polemon twice. In the Quaestiones Convivales he praises him as "a polymath and no slouch in Hellenic matters", while citing him (here as "Polemon the Athenian") concerning a dedication in the treasury of the Sicyonians at Delphi. ${ }^{78}$ The other citation occurs in the Aratus, where Plutarch tells at some length an amusing tale about a painting of the Sicyonian tyrant Aristratus, pictured alongside a chariotmounted Nike, which the painter Nealces rescued from destruction at the hands of Aratus by offering to paint over the image of the offending tyrant. ${ }^{79}$ Polemon may also be responsible for the narrative that frames this story, which concerns Aratus's shipment of paintings to Ptolemy Philadelphus in Egypt. Then in the following chapter it is possible that Plutarch owed to Polemon the text of a six-line epigram carved on the base of a statue of Aratus, the only (explicit) quotation of an inscription in the biography. ${ }^{80}$ In any case, it is all but certain that Plutarch again turns to Polemon later in the Aratus, when he refers to a painting by Timanthes that depicted Aratus's victory over the Aetolians at Pellene. ${ }^{81}$ Given Polemon's familiarity with Sicyon and its monuments, the possibility that Plutarch returned to him for a final time for his account of the festival of Aratus should be seriously considered. ${ }^{82}$ 


\section{Conclusion} annually in honor of Aratus derived ultimately from an inscribed decree. The list of the participants bears an unmistakable resemblance to the lists of marchers that are a characteristic feature of Hellenistic inscriptions concerned with the organization of

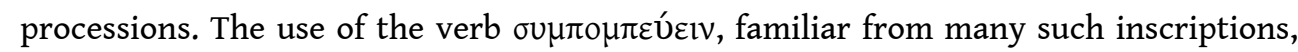
reinforces the impression of an epigraphic origin. Moreover, the detail that the priest of Aratus wore a strophion that was "not completely white but purple-striped" reads more like a requirement of his office than anything an observer of the procession is likely to say. Similarly, the statement that "any other of the citizens who wished"

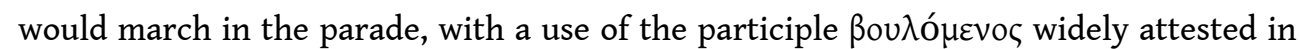
inscriptions of a variety of sorts, is appropriate to a provision of a decree granting permission to all male citizens to attend, not to the remarks of a spectator. As with the information about the priest's headwear, this is prescriptive, not descriptive, language.

I have also argued that it is improbable that Plutarch saw and transcribed the presumed inscription himself. Even if he had been to Sicyon (which is doubtful) and the inscription was still in place for him to see (uncertain), what we know of the habits and inclinations of the bookish Plutarch suggests that he would much more likely have known of the festival from a literary source. I have tentatively identified this source as Polemon, an avid epigraphist who knew Sicyon well and whose habits and inclinations seem on the whole to have been very different from Plutarch's. Certainly of the six authors cited by name in the Aratus - and for that matter of all authors known to us Polemon is the only one who should be considered a possible source for the information about the festival. Whether Polemon (or, if you prefer, Plutarch's unnamed source here) was also responsible for the story about the ancient law, the oracle, and the return of the body to Sicyon is difficult to say: surely this is not Polybius. ${ }^{83}$ As far as we can tell, Polemon did not publish bare collections of inscriptions without any historical context and commentary ${ }^{84}$ So, if I am right that Polemon was Plutarch's source for the description of the festival, then it is probable that he was also his source for the events immediately following Aratus's death. ${ }^{85}$

If much of my commentary on Aratus, 53 has been necessarily speculative, there are a few things that are certain or at least highly probable. Polemon lived for a time, months if not years, in Sicyon, where he studied and wrote about the paintings to which the city owed much of its renown. There can be little doubt that he knew the monument of Sicyon's most celebrated citizen. It is very likely that set up nearby was a stele recording the foundation of the cult of Aratus - which must have included a section stipulating the order of the participants in the sacrificial procession - and that Polemon knew the inscription as well. There is also no reason to doubt that the festival continued to be celebrated into the first few decades of the second century BC; so it is conceivable (and an intriguing possibility) that Polemon attended the festival himself during his residence in the city. ${ }^{86}$ Whether or not a line has been convincingly drawn between the Perigete's experiences in Sicyon and Plutarch's composition of his biography of Aratus some three centuries later I leave to the reader to decide. At the very least I hope to have shown that there is more to Plutarch's description of the cult of Aratus at Sicyon than initially meets the eye. 


\section{Abbreviations}

\begin{tabular}{|c|c|}
\hline Achaïe II & 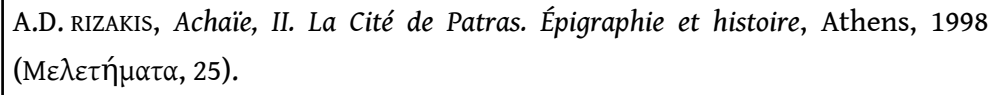 \\
\hline Choix-Delphes & $\begin{array}{l}\text { A. JACQUEMIN, D. MULLIEZ, G. ROUGEMONT, Choix d'inscriptions de Delphes, traduites et } \\
\text { commentées, Athens, } 2012 \text { (Études épigraphiques, 5). }\end{array}$ \\
\hline F.Delphes III, 1 & $\begin{array}{l}\text { É. BOURGUET, Fouilles de Delphes, III. Épigraphie, 1. Inscriptions de l'entrée du } \\
\text { sanctuaire au trésor des Athéniens, Paris, 1910-1929. }\end{array}$ \\
\hline F.Delphes III, 2 & $\begin{array}{l}\text { G. Colin, Fouilles de Delphes, III. Épigraphie, 2. Inscriptions du trésor des Athéniens, } \\
\text { Paris, 1909-1913. }\end{array}$ \\
\hline GVI & W. РЕEK, Griechiscshe Vers-Inschriften, I. Grab-Epigramme, Berlin, 1955. \\
\hline I.Cret. & M. GUARDUCCI, Inscriptiones Creticae, 4 vols., Rome, 1935-1950. \\
\hline I.Délos & Inscriptions de Délos, 7 vols., Paris, 1926-1972. \\
\hline I.Iasos I & W. BLÜMEL, Die Inschriften von Iasos, I, Bonn, 1985 (IK, 28, 1). \\
\hline I.Knidos I & W. BLÜMEL, Die Inschriften von Knidos, I, Bonn, 1992 (IK, 41). \\
\hline I.Lampsakos & P. FRISCH, Die Inschriften von Lampsakos, Bonn, $1978(I K, 6)$. \\
\hline I.Magnesia & O. KERN, Die Inschriften von Magnesia am Maeander, Berlin, 1900. \\
\hline I.Napoli I & E. MIRANDA, Iscrizioni greche d'Italia. Napoli, I, Rome, 1990. \\
\hline I.Stratonikeia II, 1 & $\begin{array}{l}\text { M.ç. §AHIN, Die Inschriften von Stratonikeia, II, 1. Lagina, Stratonikeia und } \\
\text { Umgebung, Bonn, } 1982(I K, 22,1) .\end{array}$ \\
\hline I.Pergamon I & $\begin{array}{l}\text { M. FRÄNKEL, Die Inschriften von Pergamon, I (Altertümer von Pergamon, VIII, 1), } \\
\text { Berlin, } 1890 .\end{array}$ \\
\hline LSAM & F. sокоLоWSKI, Lois sacrées de l'Asie Mineure, Paris, 1955. \\
\hline LSCG & F. SOKOLOWSKI, Lois sacrées des cités grecques, Paris, 1969. \\
\hline LSS & F. SокоLоWSкI, Lois sacrées des cités grecques. Supplément, Paris, 1962. \\
\hline $\begin{array}{l}\text { MERKELBACH } \\
\text { STAUBER, SGO I }\end{array}$ & $\begin{array}{l}\text { R. MERKELBACH, J. STAUBER, Steinepigramme aus dem griechischen Osten, I. Die } \\
\text { Westküste Kleinasiens von Knidos bis Ilion, Stuttgardt/Leipzig, } 1998 \text {. }\end{array}$ \\
\hline NGSL & $\begin{array}{l}\text { E. LUPU, Greek Sacred Law. A Collection of New Documents, Leiden/Boston, } 2009^{2} \\
{[2005](R G R W, 152) \text {. }}\end{array}$ \\
\hline
\end{tabular}

\section{BIBLIOGRAPHY}

P. AMANDRY, La Mantique apollinienne à Delphes. Essai sur le fonctionnement de l'Oracle, Paris, 1950

(BEFAR, 170). 
S. ANEZIRI, Die Vereine der dionysischen Techniten im Kontext der hellenistischen Gesellschaft. Untersuchungen zur Geschichte, Organisation und Wirkung der hellenistischen Technitenvereine, Stuttgart, 2003 (Historia Einzelschriften, 163).

-, "The Organization of Music Contests in the Hellenistic Period and Artists' Participation: An Attempt at Classification", in P. WILSON (ed.), The Greek Theatre and Festivals. Documentary Studies, Oxford, 2007 (Oxford Studies in Ancient Documents), p. 67-84.

S. ANEZIRI, D. DAMASKOS, "Städtische Kulte im hellenistischen Gymnasion", in KAH - SCHOLZ (2004), p. 247-271.

A. BÉLIS, “Cithares, citharistes et citharôdes en Grèce”, CRAI 139 (1995), p. 1025-1065.

F. вÖMER, s.v. “Pompa (

H. BowDEn, Classical Athens and the Delphic Oracle. Divination and Democracy, Cambridge, 2005.

F.E. BRENK, S.J., In Mist Apparelled. Religious Themes in Plutarch's Moralia and Lives, Leiden, 1977 (Mnemosyne Suppl., 48).

J. BUCKLER, "Plutarch and Autopsy", ANRW II, 33, 6 (1992), p. 4788-4830.

M. CARROLL, Spirits of the Dead. Roman Funerary Commemoration in Western Europe, Oxford, 2006 (Oxford Studies in Ancient Documents).

J. CASABONA, Recherches sur le vocabulaire des sacrifices en grec, des origines à la fin de l'époque classique, Aix-en-Provence, 1966 (Publication des Annales de la Faculté des lettres, Aix-en-Provence, n.s., 56).

L. CASSON, Ships and Seamanship in the Ancient World, Princeton, 1971.

A. CHANIOTIS, "Sich selbst feiern? Städtische Feste des Hellenismus im Spannungsfeld von Religion und Politik", in M. WÖRRLE, P. ZANKER (eds.), Stadtbild und Bürgerbild im Hellenismus. Kolloquium, München, 24. bis 26. Juni 1993, Munich, 1995 (Vestigia, 47), p. 147-172.

-, "Griechische Rituale der Statusänderung und ihre Dynamik", in M. STEINICKE, S. WEINFURTER (eds.), Investitur- und Krönungsrituale. Herrschaftseinsetzungen im kulturellen Vergleich, Cologne, 2005, p. 43-61.

-, "The Dynamics of Ritual Norms in Greek Cult", in. P. BRULÉ (ed.), La Norme en matière religieuse en Grèce antique. Actes du XI colloque du CIERGA (Rennes, septembre 2007), Liège, 2009 (Kernos, Suppl. 21), p. 91-105.

-, "Processions in Hellenistic Cities: Contemporary Discourses and Ritual Dynamics", in R. ALSTON, O.M. VAN NIJF, C.G. WILLIAMSON (eds.), Cults, Creeds and Identities in the Greek City after the Classical Age, Leuven/Paris/Walpole, Mass., 2013, p. 21-47.

A.S. CHANKOWSKI, "Processions et cérémonies d'accueil : une image de la cité de la basse époque hellénistique ?”, in FRÖHLICH - MÜLLER (2005), p. 185-206.

É. CHIRICAT, "Funérailles publiques et enterrement au gymnase à l'époque hellénistique", in FRÖHLICH - MÜLLER (2005), p. 207-223.

K. CLINTON, The Sacred Officials of the Eleusinian Mysteries, Philadelphia, 1974 (TAPhS, n.s., 64, 3).

J.B. Connelly, Portrait of a Priestess. Women and Ritual in Ancient Greece, Princeton/Oxford, 2007.

E. CRESPO GÜEMES, “Plutarcho y la epigrafia”, in R.M. AGUILAR, M. LÓPEZ SALVÁ, I. RODRíGUEZ ALFAGEME (eds.), Xópıı $\delta 1 \delta \alpha \sigma \kappa \alpha \lambda i ́ \alpha c$. Studia in honorem Ludovici Aegidii. Homenaje a Luis Gil, Madrid, 1994, p. $145-154$. 
E. CSAPO, W.J. SLATER, The Context of Ancient Drama, Ann Arbor, 1994.

o. CURTY (ed.), L'Huile et l'Argent. Gymnasiarchie et évergétisme dans la Grèce hellénistique. Actes du colloque tenu à Fribourg du 13 au 15 octobre 2005, publiés en l'honneur du Prof. Marcel Piérat à l'occasion de son $60^{\circ}$ anniversaire, Paris, 2009.

O. CURTY, Gymnasiarchika. Recueil et analyse des inscriptions de l'époque hellénistique en l'honneur des gymnasiarques, Paris, 2015 (De l'archéologie à l'histoire).

K. DEICHGRÄBER, “Polemon (9), von Ilion, Periheget”, RE XXI, 2 (1952), col. 1288-1320.

J. DELORME, Gymnasion. Étude sur les monuments consacrés à l'éducation en Grèce (des origines à l'Empire romain), Paris, 1960 (BEFAR, 196).

N. DESHOURS, Les Mystères d'Andania. Études d'épigraphie et d'histoire religieuse, Bordeaux, 2006

(Scripta Antiqua, 16).

P. DESIDERI, “I documenti di Plutarcho”, ANRW II, 33, 6 (1992), p. 4536-4567.

F. DUNAND, "Sens et fonction de la fête dans la Grèce hellénistique. Les cérémonies en l'honneur d'Artémis Leucophryéné", DHA 4 (1978), p. 201-218.

R.M. ERRINGTON, Philopoemen, Oxford, 1969.

L.R. FARNELL, Greek Hero Cults and Ideas of Immortality, Oxford, 1921.

R. FlaCelière, É. ChAmbry, Plutarque. Vies. Tome XV. Artaxerxès - Aratus - Galba-Othon, Paris, 1979.

J. FONTENROSE, The Delphic Oracle. Its Responses and Operations with a Catalogue of Responses, Berkeley/ Los Angeles/London, 1978.

M.P. FOUCART, Le culte des héros chez les Grecs, Paris, 1922 (Mémoires de l'Académie des inscriptions et belles-lettres, 42, p. 1-166).

P. FRÖHLICH, "Funérailles publiques et tombeaux monumentaux intra-muros dans les cités grecques à l'époque hellénistique", in M.-C. FERRIÈs, M. P. CASTIGLIONI, F. LÉTOUBLON (eds.), Forgerons, élites et voyageurs d'Homère à nos jours. Homages en mémoire d'Isabelle Ratinaud-Lachkar, Grenoble, 2013, p. 227-309.

P. FRÖHLICH, C. MÜLLER (eds.), Citoyenneté et participation à la basse époque hellénistique, Geneva, 2005 (École pratique des hautes études, Sciences historiques et philologiques, III. Hautes études du monde grécoromain, 35).

P. GAUTHIER, “Études sur des inscriptions d'Amorgos”, BCH 104 (1980), p. 197-220.

-, Les cités grecques et leur bienfaiteurs (IV -I $^{\text {er }}$ siècle av. J.-C.). Contribution à l'histoire des institutions, Paris, 1985 (BCH, Suppl. 12).

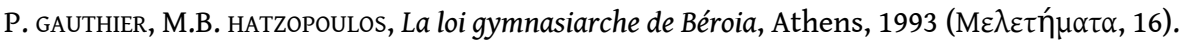

L.C. GAWLINSKI, The Sacred Law of Andania. A New Text with Commentary, Berlin/Boston, 2012

(Sozomena, 11).

D. GNEISZ, Das antike Rathaus. Das griechiscshe Bouleuterion und die frührömische Curia, Vienna, 1990 (Dissertationen der Universität Wien, 205).

C.F.G. GolTZ, Quibus fontibus Plutarchus in vitis Arati, Agidis, Cleomenis enarrandis usus sit, Insterburg, 1883.

F. GRAF, Nordionische Kulte. Religionsgeschichtliche und epigraphische Untersuchungen zu den Kulte von Chios, Erythrai, Klazomenai und Phokaia, Rome 1985 (Bilbliotheca Helvetica Romana, 21). 
A. GRIFFIN, Sicyon, Oxford, 1982.

C. HABICHT, Gottmenschentum und griechische Städte', Munich, $1970^{2}$ [1956] (Zetemata, 14).

W.R. HALLIDAY, The Greek Questions of Plutarch, Oxford, 1928.

E.M. HARRIS, “Toward a Typology of Greek Regulations about Religious Matters: A Legal

Approach", Kernos 28 (2015), p. 53-83.

R. HEBERDEY, E. KALINKA, Bericht über zwei Reisen im südwestlichen Kleinasien, Vienna, 1896

(Denkschriften der Kaiserlichen Akademie der Wissenschaften in Wien, philosophisch-historische Classe, $45,1)$.

W.C. HELMBOLD, E.N. o'NEIL, Plutarch's Quotations, Baltimore/Oxford, 1959 (American Philological Association Philological Monographs, 19).

O. HENRY (ed.), Le Mort dans la ville. Pratiques, contextes et impacts des inhumations intra-muros en Anatolie, du début de l'Âge du Bronze à l'époque romaine, Istanbul, 2013 ( $2^{e}$ Rencontres d'archéologie de L'IFÉA).

C. HIGBIE, “Craterus and the Use of Inscriptions in Ancient Scholarship", TAPA 129 (1999), p. 43-83. D.D. HUGHES, "Hero Cult, Heroic Honors, Heroic Dead: Some Developments in the Helllenistic and Roman Periods”, in R. HÄGG (ed.), Ancient Greek Hero Cult, Stockholm, 1999 (ActAth-in 8 16), p. 167175.

-, "Sacrifice and the Cult of the Dead in Ancient Argos", in R. HÄGG, B. ALROTH (eds.), Greek Sacrificial Ritual, Olympian and Chthonian, Stockholm, 2005 (ActAth-in 8', 18), p. 75-83.

W. HUTTON, Describing Greece. Landscape and Literature in the Periegesis of Pausanias, Cambridge, 2005 (Greek Culture in the Roman World).

C. JONES, "Processional Colors", in B. BeRgMAn, C. KONDOLEON (eds.), The Art of Ancient Spectacle, Washington, DC, 1999 (Studies in the History of the Arts, 56), p. 247-257.

-, New Heroes in Antiquity, Cambridge, Mass./London, 2010.

D. КАН, P. SCHOLZ (eds.), Das hellenistische Gymnasion, Berlin, 2004 (Wissenskultur und gesellschaftlicher Wandel, 8).

P. KATÓ, “The Funeral of Philopoimen in the Historiographical Tradition", in E. STAVRIANOPOULOU (ed.), Ritual and Communication in the Graeco-Roman World, Liège, 2006 (Kernos, Suppl. 16), p. 239250 .

J. KÖHLER, Pompai. Untersuchungen zur hellenistichen Festkultur, Frankfurt am Main, 1996 (Europäische Hochschulschriften, ser. XXXVIII [Archäologie], 61).

A.J. KOSTER, Plutarchi Vita Arati, Leiden, 1937.

I. KRALLI, The Hellenistic Peloponnese: Interstate Relations. A Narrative and Analytic History, from the Fourth Century to 146 BC, Swansea, 2017.

D.C. KURTZ, J. BOARDMAN, Greek Burial Customs, London, 1971.

B. LAUM, Stiftungen in der griechischen und römischen Antike. Ein Beitrag zur antiken Kulturgeshichte, 2 vols., Leipzig/Berlin, 1914.

B. LE GUEN, Les Associations de Technites dionysiaques à l'époque hellénistique, 2 vols., Nancy, 2001

(Études d'Archéologie Classiques, 11-12). 
W. LESCHHORN, “Gründer der Stadt”. Studien zu einem politisch-religiösen Phänomen der griechischen Geschichte, Stuttgart, 1984 (Palingenesia, 20).

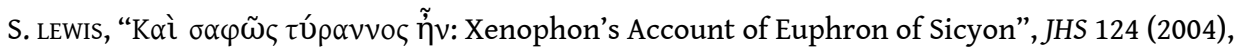
p. 65-74.

P.P. LIDDEL, "Scholarship and Morality: Plutarch's Use of Inscriptions”, in A.J. NIKOLAIDIS (ed.), The Unity of Plutarch's Work. 'Moralia' Themes in the 'Lives', Features of the 'Lives' in the 'Moralia', Berlin, 2008, p. 125-137.

J. L. LIGHTFOOT, "Nothing to do with the technitai of Dionysus?", in P. EASTERLING, E. HALL (eds.), Greek and Roman Actors. Aspects of an Ancient Profession, Cambridge, 2002, p. 209-224.

Y. LoLos, Land of Sikyon. Archaeology and History of a Greek City-State, Athens, 2011 (Hesperia, Suppl. 39).

Y. LOLOS, B. GOURLEY, “The Town Planning of Hellenistic Sikyon”, AA 2011, p. 87-140.

N. LURAGHI, A. MAGNETTO, “The Controversy between Megalopolis and Messene in a New Inscription from Messene (With an Appendix by Christian Habicht)", Chiron 42 (2012), p. 509-550.

I. MALKIN, Religion and Colonization in Ancient Greece, Leiden/New York, 1987 (Studies in Greek and Roman Religion, 3).

E. MANGO, “Bankette im hellenistischen Gymnasion”, in KAH - sCHOLZ (2004), p. 273-311.

R. MARTIN, Recherches sur l'agora grecque. Études d'histoire et d'architecture urbaines, Paris, 1951 (BEFAR, 174).

W.A. MCDONALD, The Political Meeting Places of the Greeks, Baltimore, 1943 (The Johns Hopkins University Studies in Archaeology, 34).

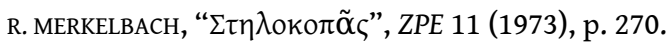

A.D. NOCK, “The Cult of Heroes", HThR 37 (1944), p. 141-174 (republished in Essays on Religion and the Ancient World, edited by z. STEWART, vol. II, Cambridge, Mass., 1972, p. 575-602).

D. oGDEN, “Controlling Women's Dress: Gynaikonomoi ”, in L. LLEWELLEN-JONES (ed.), Women's Dress in the Ancient Greek World, London, 2002, p. 203-225.

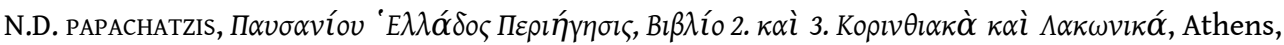
1976.

H.W. PARKE, D.E.W. WORMELL, The Delphic Oracle, 2 vols., Oxford, 1965.

R. PARKER, Miasma. Pollution and Purification in Early Greek Religion, Oxford, 1983.

-, “New ‘Panhellenic’ Festivals in Hellenistic Greece”, in R. SCHLESIER , U. ZELLMANN (eds.), Mobility and Travel in the Mediterranean from Antiquity to the Middle Ages, Münster, 2004 (Reiseliteratur und Kulturanthroplogie, 1), p. 9-22.

St. PAUL, Cultes et sanctuaires de l'île de Cos, Liège, 2013 (Kernos, Suppl. 28).

-, "Sharing the Civic Sacrifice: Civic Feast, Procession, and Sacrificial Division in the Hellenistic Period", in F. VAN DEN EIJNDE, J. BLOK, R. STROOTMAN (eds.), Feasting and Polis Institutions, Leiden, 2018 (Mnemosyne Suppl., 414), p. 315-339.

F. PFISTER, Der Reliquienkult im Altertum, Giessen, 1909-1912 (RGVV, 5, 1-2).

A.W. PICKARD-CAMBRIDGE, The Dramatic Festivals of Athens, revised by J. GOULD and D.M. LEWIS, Oxford, $1988^{2}[1968,1953]$. 
W.H. PORTER, Plutarch's Life of Aratus, Dublin/Cork, 1937.

L. PRELLER, Polemonis Periegetae Fragmenta, Leipzig, 1838 [reprint ed. Chicago, 1969].

B. PUECH, “Grands-prêtres et helladarques d'Achaïe”, REA 85 (1983), p. 15-45.

B. PUECH, "Prosopographie des amis de Plutarque", ANRW, II, 33, 6 (1992), p. 4895-4915.

L. ROBERT, “Sur des inscriptions de Chios”, BCH 57 (1933), p. 505-543.

-, "Notes d'épigraphie hellénistique”, BCH 59 (1935), p. 421-437.

-, Études anatoliennes. Recherches sur les inscriptions grecques de l'Asie mineure, Paris, 1937 (Études orientales publiés par l'Institut français d'archéologie de Stamboul, 5).

-, “Inscriptions d'Aphrodisias. Première partie”, AC 35 (1966), p. 377-432.

G. Roux, Pausanias en Corinthie (Livre II, 1 à 15), Paris, 1958 (Annales de l'Université de Lyon, ser. 3, Lettres, 31).

P. SCHMITT-PANTEL, La cité au banquet. Histoire des repas publics dans les cités grecques, Paris, 1992

(Collection de l'École française de Rome, 157).

H. SCHÖRNER, Sepulturae Graecae intra urbem. Untersuchungen zum Phänomen der Intraurbanen Bestattungen bei den Griechen, Möhnesee, 2007 (Boreas, 9).

C. SCHULER, “Die Gymnasiarchie in hellenistischer Zeit”, in KAH - SCHOLZ (2004), p. 163-192.

F.F. schulz, Quibus ex fontibus fluxerint Agidis, Cleomenis, Arati Vitae Plutarcheae, Berlin, 1886.

H. SEYRIG, "Inscriptions de Gythion", RA, ser. 5, 29 (1929), p. 84-106.

C.H. SKALET, Ancient Sicyon with a Prosopographia Sicyonia, Baltimore, 1928.

F. SOKOLOWSKI, "Divine Honors for Antiochus and Laodike at Teos and Iasos", GRBS 13 (1972), p. $171-176$.

F. TAEGER, Charisma. Studien zur Geschichte des antiken Herrscherkultes, 2 vols., Stuttgart, 1957-1960.

A. TRESP, Die Fragmente der griechischen Kultschriftsteller, Giessen, 1914 (RGVV, 15.1).

M. TREU, J. DAEHNER, J.B. GROSSMAN, K.D.S. LAPATIN, “Greek Processions”, ThesCRA I (2004), p. 1-20.

F.T. VAN STRATEN, Hiera Kala. Images of Animal Sacrifice in the Ancient World, Leiden/New York, 1995 $(R G R W, 127)$.

F.W. WALBANK, Aratos of Sicyon, Cambridge, 1933.

-, A Historical Commentary on Polybius, 3 vols., Oxford, 1957-1979.

H.D. WESTLAKE, “The Sources of Plutarch's Timoleon”, CQ 32 (1938), p. 65-74.

\section{NOTES}

1. Plutarch, Aratus, 52; Polybius, VIII, 12, 2-6; Livy, XXXII, 21, 23-24; Pausanias, II, 9, 4 and VIII, 50, 4. Scholars have doubted the allegation of poisoning, favoring disease (tuberculosis) instead: PORTER (1937), p. 84 (on Arat., 52, 2); WALBANK (1957-1979), vol. II, p. 87-88 (on Polyb., VIII, 12, 2-5). 2. Plut., Arat., 53, 1-7. Except for capitalization and some punctuation I largely follow the text of FLACELIÈRE - CHAMBRY (1979). There are minor problems. In 53, 4, I retain with these editors the

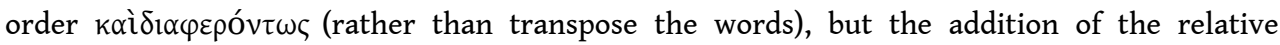




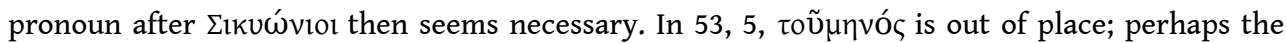
double parallelism, with ellipses - "the (sacrifice) / the day on which ... the (sacrifice) / (the day) on which" - caused confusion. Intelligibility would be improved with the addition of a second

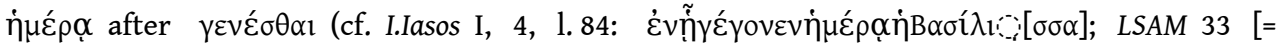

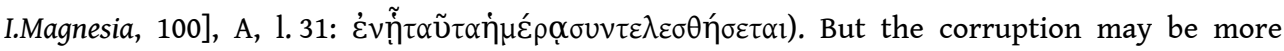
extensive, since we would expect Plutarch to give a precise date, as he does for the Soteria.

3. Cf. JONES (1999), p. 248: "Plutarch's description reads so like one of the many regulations that survive in epigraphy that we may suspect some sacred law to be his ultimate source", an observation I came across only late in the development of my thesis. I aim here not only to substantiate with parallels what Jones remarked in passing but also to use the parallels to supplement Plutarch's account, writing a sort of epigraphic commentary on the passage.

4. See below, n. 31 and 40 .

5. Plut., Arat., 53, 1-5; Paus., II, 8, 1 (cf. II, 9, 4 and 6).

6. PFISTER (1909-1912), p. 192; FARNELL (1921), p. 348-349; FOUCART (1922), p. 141; SKALET (1928), p. 19 and 174-175; WALBANK (1933), p. 157; KOSTER (1937), p. liii and 127-128; PORTER (1937), p. 85-86; NOCK (1944), p. 147 (581); TAEGER (1957-1960), vol. I, p. 363; WALBANK (1957-1979), vol. II, p. 89; PAPACHATZIS (1976), p. 102 n. 4; GRIFFIN (1982), p. 84; PARKER (1983), p. 42-43; LESCHHORN (1984), p. 326; MALKIN (1987), p. 233-236; SCHÖRNER (2007), p. 14-16; JONES (2010), p. 33; LOLOS (2011), p. 382; FRÖHLICH (2013), p. 250-254; KRALLI (2017), p. 300 (I must include myself in this list, in a brief summary: HUGHES [1999], p. 171-172).

7. Polyb., VIII, 12, 7-8; Paus., II, 9, 4. Plutarch's account is longer, certainly, but still quite superficial: note that the actors are not individuals but simply "the Achaeans" and "the Sicyonians". Note also the emotional coloring and rapid reversals: the ambition (

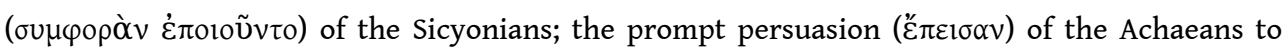
release the body, followed by a collective pang of superstitious dread ( $\delta \varepsilon 1 \sigma 1 \delta \alpha \iota \mu o v i ́ \alpha \varsigma)$; and finally the joy of both parties (ทँ $\sigma \eta \sigma \alpha v)$ upon reception of the oracle.

8. The oracle was accepted as authentic by PARKE, WORMELL (1965), vol. I, p. 260, and vol. II, p. 144145 (no. 358), where they posited a lacuna after line 2. FonTENRoSe (1978), p. 345 (no. Q235) rejected it as "not genuine". On verse oracles see AMANDRY (1950), p. 164-168; FONTENROSE (1978), p. 166-195; and more recently, BOWDEN (2005), p. 33-38, who discusses (p. 34) Plut., Moralia (De Pythiae oraculis, 22-24), 405c-406d, according to which the Pythia would no longer be delivering verse oracles as late as the third century BC; cf. Cicero, De divinatione, II, 116 (... Pyrrhi temporibus iam Apollo versus facere desierat).

9. If consultations of the oracle were restricted to one day a month at this time (see e.g. HALLIDAY [1928], p. 61-62; AMANDRY [1950], p. 81-85; BOWDEN [2005], p. 17), then our hypothetical Sicyonian envoy would have to be very lucky - or else out of luck. From Itea to the sanctuary of Apollo Google Maps (http://maps.google.gr) gives three possible routes on foot, $12.4 \mathrm{~km}, 14.9 \mathrm{~km}$, and $17.3 \mathrm{~km}$, which take from 3 hours and 8 minutes to 4 hours and 8 minutes to cover; I do not know if these estimates adequately take into account the steepness of the climb (from 5 to 586 meters above sea level), but in any case the routes follow modern roadways. How long it would have taken to cross the gulf from Aigion to Itea would depend on a number of factors: the availability of a ship and the type of vessel, the route taken, the time of year, and the weather, in particular the force and direction of the winds. The distance as the crow flies is around $35 \mathrm{~km}$; the sailing distance would be something like $45 \mathrm{~km}$, or around 24 nautical miles, which at 4 knots would take 6 hours, at a brisker 6 knots, 4 hours, to cover (cf. CAsson [1971], p. 281-291; I thank Andrew Stewart, Jake Kirchner, and Georgia Irby for discussing nautical matters with me at various times). The distance from Aigion to Kiato is $70.6 \mathrm{~km}$, a walk of 14 hours, 35 minutes, along the Patras-Corinth highway; the hike from there up to Sicyon adds another $5 \mathrm{~km}$. This would have 
taken considerably longer in antiquity, especially for a group conveying a corpse on a wagon; it therefore seems possible that, weather permitting, the body would have been transported from Aigion by sea (cf. Plut., Arat., 42, 2, where a living Aratus goes by boat in the opposite direction, in this case to elude detection).

10. See KURTZ, BOARDMAN (1971), p. 144-146, with references p. 360.

11. Polyb., XXIII, 12, 3; Livy, XXXIX, 50, 7-8; Plut., Philopoemen, 20; Paus., VIII, 51, 7; for the alleged poisoning by Deinocrates see ERRINGTON (1969), p. 191-193; WALBANK (1957-1979), vol. III, p. 241 (on Polyb., XXIII, 12, 3).

12. Plut., Phil., 21, 3-9; Diodorus Siculus, XXIX, 18. Inscription: Syll. ${ }^{3}, 624$ (= IG V 2, 432), 1. 5-9 (monument, remains, altar); 1.9-10 and 39-41 (Zeus Soter); 1.10-15 (statues); there is also mention (l. 42) of a temenos ( $\tau \varepsilon \dot{\mu} \mu v \varepsilon \varsigma$ ) of Philopoemen. For the death and funeral see ERRINGTON (1969), p. 189-194 and 241-245; LESCHHORN (1984), p. 330-331; KATó (2006); LURAGHI - MAGNETTO (2012), p. 519-520 and 540. For the cult see also SCHÖRNER (2007), p. 76 and 274-275, and FRÖHLICH (2013), p. 255-257, with a detailed discussion of the inscription.

13. I.e. with Polybius as the ultimate source of all accounts. Even so, there are uncertainties, in the chronology in particular. Plutarch gives the impression that the campaign against Messene was over in a matter of days (Phil., 21, 1-2; cf. Paus., VIII, 51, 8), but it is generally held to have taken up to two months to complete, between two regular meetings of the Achaean Confederacy (Plut., Phil., 21, 1; Polyb., XXIII, 16): so ERRINGTON (1969), p. 195 and 241-245, followed by KATó (2006), p. 244-245, and KRALLI (2017), p. 348-349 and 361-363. If the conflict was indeed more protracted than Plutarch's rapid narrative lets on, then it is probable that Philopoemen's body was burned - not, as in Plutarch, by the Achaeans but - by the Messenians themselves; and this in fact is what is implied in Livy's succinct account, where the bones (i.e. the remains of a cremation) are said to have been returned to the Achaeans by Messene (XXXIX, 50, 9: ... ossaque reddita Philopoemenis sunt); the inscription also refers to cremated remains ( $\tau[\grave{\alpha}]$ ó $\left.\sigma \varepsilon \varepsilon_{\alpha} \alpha\right)$ that are apparently still in Messene at the time of the decree (Syll. $\left.{ }^{3}, 624,1.6-7\right)$. But my point here is simply that, in cases where someone died far from home or there was to be some other delay before burial was possible, the body would normally be cremated. Thus when Demetrius Poliorcetes died in Syria his body was burned and the ashes taken by ship to Corinth, and from there to Demetrias in Thessaly for burial (Plut., Demetrius, 53, 1-7). The bodies of Spartan kings who died abroad would be encased in honey (or, this wanting, wax) and brought home for burial (Agesipolis: Xenophon, Hellenica, V, 3,19; Agesilaus: Plut., Agesilaus, 40, 4; cf. Diod. Sic., XV, 93, 6; Cornelius Nepos, Agesilaus, 8, 7); but among the Greeks the practice seems to have been peculiar to the Spartans and reserved for their kings. For a much later instance, from late Republican Rome, see CARROLL (2006), p. 164 with n. 77.

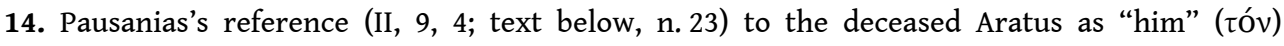
suggests a corpse, not the remains of a cremation, and thus offers slight confirmation of Plutarch's vekpóv. Among other details of Plutarch's account, it is not implausible that there was a dispute, or at least a discussion, between Aratus's countrymen and the other members of the Confederacy about the place of burial. But the rest seems to me more good story than good history.

15. It is unlikely that Plutarch invented this story himself, but the "powerful superstition" may be his own addition. Not only is desidaimonia a common word (102 occurrences) and an important concept in Plutarch's writing (BRENK [1977], p. 9-15 and 59-64), but he uses it specifically of the Spartans' superstitious fear about burying their dead inside of the city, which Lycurgus sought to dispel (Lycurgus, 17, 1; Mor. [Instituta Laconica, 18], 238d). This does not seem to be pure coincidence.

16. See e.g. SCHÖRNER (2007), p. 202-205; KURTZ - BOARDMAN (1971), p. 91-96 (on Athens). Most excavated burials on the periphery of Sicyon apparently remain unpublished; but see LoLOS 
(2011), 201-204 and 283-284; LOLOS - GOURLEY (2011), p. 101. Pausanias (II, 7, 2-4) saw several graves on the roadside as he approached the city from the east.

17. Schol. Pindar, Olympian 1, l. 149 [93] (oijò̀ cited by PFISTER (1909-1912), p. 445; HABICHT (1970), p. 205 n. 49; LESCHHORN (1984), p. 103-104 n. 8; GAUTHIER (1985), p. 60 n. 180; MALKIN (1987), p. 200. For intramural burial see PFISTER (1909-1912), p. 445-449; ROBERT (1937), p. 49-50; MARTIN (1951), p. 194-201; ROBERT (1966), p. 419-421; LESCHHORN (1984), p. 103-104 and 340; GAUTHIER (1985), p. 60-66; GRAF (1985), p. 133 with n. 89-93; MALKIN (1987), p. 204240; more recently and more fully: SCHÖRNER (2007); HENRY (2013); FRÖHLICH (2013). For burial in the gymnasium specifically see CHIRICAT (2005).

18. Herodotus, V, 67; FONTENROSE (1977), p. 292-293 (no. Q74); MALKIN (1987), p. 236-237. I omit reference here to a sizable body of scholarship on the moving of heroes' bones.

19. Xen., Hell., VII, 3, 12. For Euphron see LEWIS (2004), and for his cult LESCHHORN (1984), p. 175180; MALKIN (1987), p. 232-233; SCHÖRNER (2007), p. 265-266; FRÖHLICH (2013), p. 239.

20. SEG 15, 195; PAPACHATZIS (1976), p. 101 n. 2; LOLOS (2011), p. 403-404 with fig. 6.20.

21. See especially MALKIN (1987), p. 200 and 232-237, who in a complex argument suggests that the law was enacted in reaction to the burial of Euphron and possibly also to the granting of

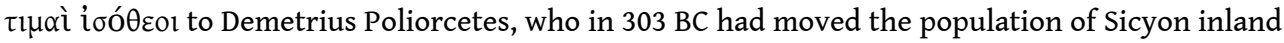
to the acropolis above the old city. "It seems reasonable to conclude...", writes Malkin, "that from 303 B.C. (at least, if not from 366 B.C.) there were no new tombs inside the city walls; to have introduced Aratos' tomb would have been a total, unprecedented novelty for the new agora of Sikyon" (p. 235). As for the earlier burials and the law's purported antiquity, Malkin must resort to special pleading: the Sicyonians "seem to have forgotten a lot of their own history" (p. 236), and the law "was somewhat anachronistically considered a most ancient one" (p. 200). For briefer and somewhat different explanations see TAEGER (1957-1960), vol. I, p. 363 n. 34, and LESCHHORN (1984), p. 327-328; FRÖHLICH (2013), p. 252, follows Leschhorn and Malkin. For the honors accorded to Demetrius while still living see Diod. Sic., XX, 102, 2-3; нABICHT (1970), p. 74-75; LESCHHORN (1984), p. 259-262. For the moving of the city see below, n. 60.

22. In fact, apart from the alleged law at Sicyon there is no good evidence that there was such a law, in the sense of a written law with penalties for violation, anywhere in Greece. The recommended regulation in Plato, Leges XII, 960a, is that the dead be taken out of the city (' $\xi \omega$ $\left.\tau \tilde{\eta} \varsigma \pi{ }^{\prime} \lambda \varepsilon \omega \varsigma\right)$ before sunrise, on the third day after death (XII, 959a); but the emphasis is on removal under cover of darkness; that the corpse be removed from the city may be a given. In $45 \mathrm{BC}$ burial intra urbem was denied to M. Marcellus by the Athenians, not on legal grounds but because of religio and a lack of precedent (Cic., Ad familiares, IV, 12, 3; on the incident see FRÖHLICH [2013], p. 278).

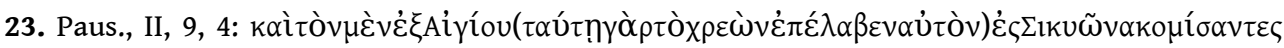

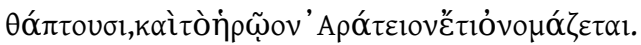

24. See HELMBOLD - O'NEIL (1959), p. 48-49 (a list of instances); BUCKLER (1992), p. 4794-4799, and, in the same volume of ANRW, DESIDERI (1992), especially 4562-4566; CRESPO GÜEMES (1994); HIGBIE (1999), p. 44-48; LIDDEL (2008).

25. Plut., Themistocles, 8, 4-5, quoted also in Mor. (De Herodoti malignitate, 34), 867f; DESIDERI (1992), p. 4564-4565; BUCKLER (1992), p. 4812; CRESPO GÜEMES (1994), p. 150. But even in this case Plutarch probably already knew the epigram (Simonides, fr. 24, ed. PAGE) and sought it out among the

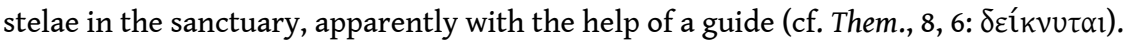

26. Arat., 14, 3-4. For the Memoirs see below, n. 71, and for another possible source for the epigram below, n. 80 .

27. The fact that Plutarch was acquainted with Polycrates, the descendant of Aratus to whom he dedicated the Life, might be taken to indicate this, but he probably knew him from Delphi, as he has been identified with the Polycrates of Mor. (De Pyth. or., 29), 409b: FLACELIÈRE - CHAMBRY (1979), 
p. 224 (on Arat., 1.1); PUECH (1983), p. 28-29 and id. (1992), p. 4874; Choix - Delphes, no. 265 (p. $452-$ 453); a Polycrates also in Mor. (Quaestiones convivales, IV, 2-V, 1), 667e-669f, set on Euboea. Plutarch also mentions the athletic physique of Aratus, as manifest in his statues (Arat., 3, 2): Pausanias saw one in the theater at Sicyon (II, 7, 5) but also one at Olympia (VI, 12, 5); and Aratus had statues in Epidaurus (IG IV ${ }^{2}$ 1, 622), Corinth (Polyb., XXXIX, 3, 10), and Argos (Plut., Arat., 45, $5)$; no doubt there were others in other places, including Delphi, where Philopoemen will later have one, erected by the Achaean koinon (Plut., Phil., 2, 1 and 10, 13; F.Delphes III, 1, 47; ChoixDelphes, no. 153). See also below, n. 81, for references to Sicyonian paintings in the Aratus. Finally, Plutarch's remark (Arat., 53, 7) that "small traces" of the rites remained in his day seems too vague for us to conclude anything about his ever having visited the city.

28. H.D. WESTLAKE (1938) argued that, in addition to Timaeus, Plutarch used a Peripatetic biography of Timoleon, itself dependent on Timaeus, but he went too far (and beyond his own stated principles) when he wrote that the Syracusan decree "was no doubt quoted by the Peripatetic biographer", to whom he also wanted to ascribe the atticizing of the text (p.72). Nepos (Timoleon, 5.4), who according the Westlake relied exclusively on the hypothetical biography, says nothing about the decree, so it is more probable that Plutarch had the decree directly from Timaeus and was himself responsible for the alterations.

29. Diod. Sic., XVI, 90, 1; Plut., Timoleon, 39, 2-6; the texts of Diodorus and Plutarch also diverge at the very end of the quotations of the decree. For the cult of Timoleon see LESCHHORN (1984), p. 196-198; MALKIN (1987), p. 239-240; ANEZIRI - DAMASKOS (2004), p. 257-258; SCHÖRNER (2007), p. 74 and 267-268; FRÖHLICH (2013), p. 239-241.

30. Funerary regulations: Plut., Mor. (Quaestiones Romanae, 26), 270f (citing Socrates) and Mor. (Quaestiones Graecae, 24), 296f-297a (no citation); the information in Mor. (Quaest. Graec., 25), 297a, is attributed to Socrates and said to have been inscribed on bronze tablets (see further HALLIDAY [1928], p. 116; HUGHES [2005], p. 81-82). Plutarch also cites Socrates in Quaest. Rom., 52. Quaest. Graec., 23, 36 (cf. Mor. [De Iside et Osiride, 35], 364f), 50, and 51 also probably come from Socrates, without citation. For the fragments of Socrates see FGrHist IIIB, 310 F 1-22, and TRESP (1914), p. 123-126.

31. The application of the term $\theta u \eta \pi$ ó $\lambda$ oৎ to the priests of Zeus Soter and Aratus is puzzling. It is

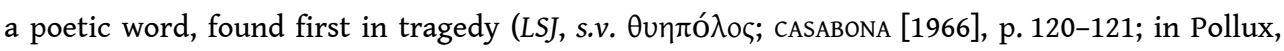

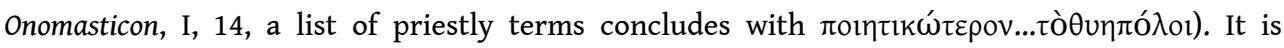
attested epigraphically in two metrical epitaphs (MERKELBACH - STAUBER, SGO I, no. 01/22 [p. 71], 1. 1: Hellenistic; IG II ${ }^{2}$, 11674 [= GVI 1029], 1. 9: late Roman), and thereafter in a few Christian inscriptions (SEG 39, 1555, 1. 3; Achaïe II, no. 186 [p. 229], 1. 2; SEG 6, 419, 1. 1; MAMA I, 254, 1. 4). It is never used in prose inscriptions, to my knowledge, of priests involved in sacrifices, processions,

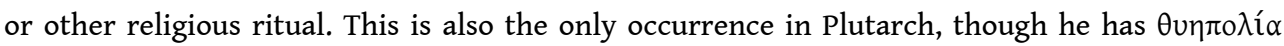
once elsewhere (Mor. [Non posse suaviter vivi secundum Epicurum], 21), 1102a, a passage with other poetic qualities). I see no good reason why Plutarch would choose to use the word in this context; it may come from his source, but this would not explain its unexpected presence here.

32. Pergamum: LSAM 11, 1. 1-4; Zeus Alseios: IG XII 4, 1, 328, 1. 15-17 (see PAUL [2013], p. 46-51; similar attire in IG XII 4, 1, 320, 1. 22-24); Nike: LSCG 163 (= IG XII 4, 1, 330), 1. 4-12 (PAUL [2013], p.151-152). Most of the instances cited here involve the sale or allotment of priesthoods; normally, incumbent priests would not need to be told what to wear. But instructions on dress would be appropriate for the newly-created priesthood of Aratus.

33. Strophiskos: LSAM 38, A, 1. 13, and B, 1. 8; Thasos: LSS 71, 1. 7-9. Andania: LSCG 65 (= IG V 1, 1390), 1. 177-179 (for the "Ten" see DESHOURS [2006], p. 92-94; GAWLINSKI [2012], p. 234-239). Eleusis: CLINTON (1974), p. 33-35 with fig. 4, 45-46, 101-104 with fig. 8-10, and Index (p. 142), s.v. "strophion". Callias: Plut., Aristides, 5, 7; CLINTON (1974), p. 47.

34. LSCG 163 (= IG XII 4, 1, 330), 1. 4-14. For distinctions in dress see also ROBERT (1935), p. 434-436. 
35. Plut., Arist., 21, 1-6. The archon would also carry a sword in the procession, though otherwise he was forbidden even to touch iron (a detail, incidentally, that could not be known from observation alone). In this case, Plutarch avers, the ritual was still practiced in his lifetime, but I see no decisive indication that he had witnessed it himself; if his source was not literary he may have spoken with an archon or priest. BUCKLER (1992), p. 4807, calls this an "eye-witness account" but confuses the quadrennial games, the Eleutheria, with the annual rites performed by the archon at the graves.

36. Delos: I.Délos, 1473, 1.7-8. Iasos: I.Iasos I, 4, 1.80-81 (193-190 BC); the supplement

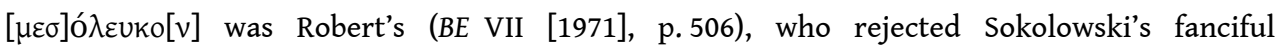

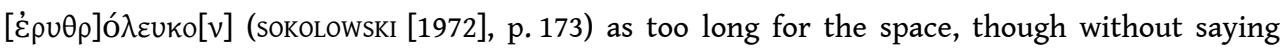
exactly how many letters are missing. For the association of white with purity see e.g. LSCG 163 (= IG XII 4, 1, 330), 1. 12-14; LSS 59, 1. 14-15; LSAM 35, 1. 3-5; Diogenes Laertius, VIII, 1, 33; CONNELLY (2007), p. 90-91. For restrictions on women's dress see LSCG 65 (= IG V 1, 1390), 1. 16-26; LSS 33, A, 1. 2-6; LSAM 6, 1. 3-7; OGDEN (2002).

37. Corope: LSCG 83, 1. 38-40; Stratoniceia: LSAM 69 (= I.Stratonikeia II, 1, 1101), 1. 7-9. Choruses: LSS 46, 1. 10; LSAM 33 (= I.Magnesia, 100), A, 1. 28-29; IG XII 9, 207, 1. 15-16 and 30-31; OGIS 309, 1. 911; paeans: LSCG 8, 1. 29-30; LSS 121, 1.12-13; LSAM 24, A, 1. 34-37; F.Delphes III, 2, 78 (= Choix Delphes, no. 123), 1. 4 (along with a pothodion and hymn); choruses and paeans together: F.Delphes III, 2, 48 (=Choix - Delphes, no. 202), 1. 21.

38. For the combination of wreaths and white clothing in literature see Pl., Resp. X, 14, 617c (of the Fates); Aeschines, III (In Ctesiphontem), 77; Philo Judaeus, Legatio ad Gaium, 12; Paus., II, 35, 5. For the combination in inscriptions see also IG XII 4, 1, 320, 1. 22-23; I.Pergamon I, 246 (=OGIS 332), 1. 38; IGR IV, 1756, 1. 11; SEG 41, 1003, II, 1. 82-83; SEYRIG (1929), no. I (p. 85-86), 1. 26-27.

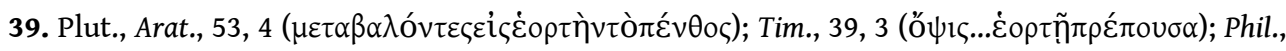

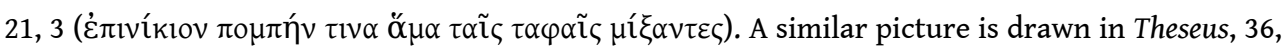
3 , where the Athenians receive the bones of Theseus into Athens with "gleaming" processions (suggestive of white clothing? cf. LSCG 83, 1.39-40; SEG 41, 1003, II, 1.82-83) and sacrifices

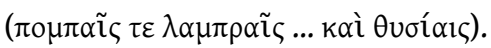

40. Where singing is involved the verb found in inscriptions seems to be invariably ợ $\delta$ ctv, the verb used by Plutarch here. Still, some of Plutarch's language is unexpected. The abrupt change

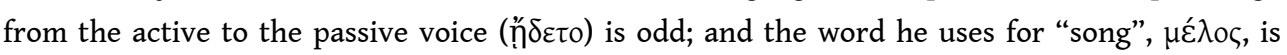
surprisingly rare in prose inscriptions, where its use seems to be confined largely to a handful of

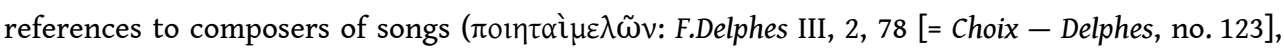
1. 4; I.Délos, 1497, 1. 6-7; IG XII 2, 519, 1. 5; I.Napoli I, 54, 1. [2]; I.Délos, 1512 [= I.Cret. I, viii, 12], 1. 6-7; SEG 18, 716, 1. 3). I suggested above ( $\$ 2.2$ ) that Plutarch may have transferred some details from an inscription-based account of the festival to his description of the Sicyonians who accompanied Aratus's body into the city. These details include not only their wreaths and white clothing but also the singing of paeans and choral performances - but with no indication of who the performers were (as the passage reads we are seemingly meant to picture the entire citizen body, after a quick change of wardrobe, erupting spontaneously into song). It seems possible that Plutarch likewise moved the paeans and choruses performed by the Artists at the festival (cf. F.Delphes III, 2, 48 [= Choix - Delphes, no. 202], 1.21; LE GUEN [2001], vol. I, p. 117-123, no. 14; ANEZIRI [2003], p. 354-356, no. A11) to his account of the funeral and replaced them with the word

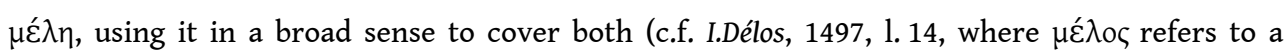

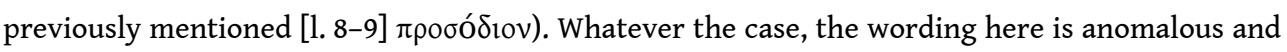
stands out in what is otherwise a close facsimile of the lists of participants in processions that we find in inscriptions of the period.

41. See especially LE GUEN (2001) and ANEZIRI (2003). For shorter treatments see e.g. PICKARDCAMBRIDGE (1988), p. 279-305 and 365, with a selection of inscriptions p. 306-321; CSAPO, SLATER 
(1994), p. 239-255, with English translations of some of the inscriptions; LIGHTFOOT (2002). For the Isthmian-Nemean koinon see LE GUEN (2001), vol. II, p. 11-13 and 17-27; ANEZIRI (2003), p. 51-70.

42. Sulla, 26, 5; Lucullus, 29, 4; Agis et Cleomenes, 33 (12), 3; Antonius, 56, 7 and 57, 1; Brutus, 21, 5; Mor. (De capienda ex inimicis utilitate, 3), 87f and (Quaest. Rom., 107), 289c.

43. Eretria: LSCG 92 (= IG XII 9, 189), 1. 5-26 and 38-40 (cf. IG XII 9, 209, 1. 20); Magnesia: LSAM 32 (= I.Magnesia, 98), 1. 45-46; Cos: LSCG 163 (= IG XII 4, 1, 330), 1. 24-29. For music and singing see also CHANIOTIS (1995), p. 161-162. For kithara players and kitharodes see BÉLIS (1995), p. 1046-1065, and, as specialists among the Dionysiac Artists, ANEZIRI (2003), p.427-428 and Index (p.513), s.v. "Kitharasänger" and "Kitharaspieler".

44. LSCG 65 (= IG V 1, 1390), 1. 29, 73-75, and 97-98. Aulos players and kithara players are specified as the technitai who would accompany dances during the sacrifices and mysteries (1.73-74) and share in the sacred meal (1.97-98); but only the aulos players are mentioned as marching in the pompe (1. 29); see further GAWLINSKI (2012), p. 139, 176-180, and 213.

45. I.Magnesia, 54, 1. 21 and 39; F.Delphes III, 2, 50, 1. 6; Ath., V, 198c (Callixenus, FGrHist IIIC, 627 F 2 , p. 169, 1. 9).

46. Aeschin., I (In Timarchum), 43; Anaximenes, Rhetorica ad Alexandrum, 2, 4 and 2, 11 (also in 38, 12); Timaeus, FGrHist IIIB, 566 F 26a (Diod. Sic., XIII, 82, 7).

47. For Greek processions see BÖMER (1952), col. 1878-1974, with a list of instances col. 1913-1974 (numbered 1-356, but with duplicates); see more recently TREU et al. (2004), with bibliography p. 1. For Hellenistic processions in particular see BÖMER (1952), col. 1895-1897, and especially CHANIOTIS (1995), p. 154-162 and id. (2013); see also KÖHLER (1996) and CHANKOWSKI (2005).

48. In approximate and often uncertain chronological order: LSCG 92 (= IG XII 9, 189), 1. 38-39 (bis); IG II ${ }^{2}, 466,1.23-24$; IG XII 9, 207, 1. 20; LSCG 177 (= IG XII 4, 1, 348), D, 1. 158-159; SEG 43, 703, 1.17 and 704, 1.12 (these, not in the PHI database [http://epigraphy.packhum.org], are cited in PAUL [2018], p. 325 n. 34); IG XII 4, 1, 298, A, 1. 20; LSCG 71, 1. 12; Syll. ${ }^{3}$, 577, 1. 76-77; I.Magnesia, 54, 1. [21] and 39; IG IV, 679, 1. 1; I.Iasos I, 4, 1. 89; LSAM 32 (= I.Magnesia, 98), 1. 36 and 55; IG XII 4, 1, 79, 1. 25-26; IG XII 4, 1, 291, 1. [7]; HEBERDEY - KALINKA (1896), 28, 1. 7; IG XII Suppl., 250, 1. 8; LSAM 81, 1. 11; I.Pergamon I, 161, 1. 4; I.Pergamon I, 246 (= OGIS 332), 1. 16; F.Delphes III, 2, 50, 1. 6; IG II ${ }^{2}, 1006$, 1. 11 and 14; LSCG 163 (= IG XII 4, 1, 330), 1.6; IGR IV, 292, 1. 45; SEYRIG (1929), no. I (p. 85-86), 1. 27. This last, from Gytheion and dating to AD 14-19, is not included in the PHI database but is cited and partially quoted by ROBERT (1933), p. 523. Still later (and also not in the PHI database) is SEG 38, 1462, C, 1.84 (Oinoanda, Lycia, AD 125; cited in NGSL, p. 97 n. 511). But the bulk of the inscriptions belong to the third and second centuries BC. For $\sigma u \mu \pi$ \% $\mu \pi \varepsilon$ viv see now PAUL (2018), p. 325-327.

49. Magnesia: LSAM 32 (= I.Magnesia, 98), 1. 32-40 and 54-55; for this inscription see KÖHLER (1996), p. 46-53, with references p. 46 n. 144; NGSL, p. 97-99; CHANIOTIS (2009), p. 103-105 and id. (2013), p. 36-37; PAUL (2018), p. 316-320. Oropos: LSCG 71 (= IG VII, 351), 1. 10-14.

50. See especially GAUTHIER - HATZOPOULOS (1993); SCHULER (2004); CURTY (2015); and the sundry contributions to CURTY (2009).

51. Antioch: LSAM 81, 1. 6-13 (on which see CHANIOTIS [2009], p. 92-93). Amorgos: IG XII 7, 515, 1. 45-49 (lampas: 1. 84-86); for this lengthy inscription see LSS 61 (1. 39-86 only), with bibliography; LAUM (1914), no. 50 (vol. II, p. 57-63); FOUCART (1922), p. 146-148; DELORME (1960), p. 209-210 and 355356; GAUTHIER (1980), p. 210-220; ANEZIRI - DAMASKOS (2004), p. 259. For youths and gymnasiarchs in processions see also LSAM 32 (= I.Magnesia, 98), 1. 38-39 (no gymnasiarch mentioned); HEBERDEY KALINKA (1896), 28, 1. 7-8; IGR IV, 292, 1. 44-45; I.Pergamon I, 246 (= OGIS 332), 1. 35-36; IG XII 4, 1, 79, B, 1. 25-27 (no gymnasiarch); IG XII 4, 1, 291, 1. 10-11; SEYRIG (1929), no. I (p. 85-86), 1. 26 (no gymnasiarch).

52. That the members of the boule would wear wreaths ( $\sigma \tau \varepsilon \varphi \alpha v \eta \varphi \circ \rho \circ \tilde{v} \sigma \alpha)$ is not surprising. In artistic representations, participants in sacrifices and pompai of sacrificial animals are usually 
pictured wreathed (see VAN STRATEN [1995], p. 161, with, e.g., fig. 11, 13, 17, 20, 30, 32, and 56). Indeed, calls for cities' entire populations to put on garlands on certain festival days seem to have been common (e.g. SEG 41, 1003, II, 1.26; IG XII 4, 1, 291, 1. 5-7; more instances in ROBERT [1933], p. 522-523). It is thus probable that officials taking part in processions would wear garlands regularly, but, if so, this is a feature that most often went without saying in decrees, presumably because there was no need to instruct officials in this. In fact, in none of the inscriptions cited below, n. 53-54, 56-57, is it said that the officials would wear wreaths (in LSCG

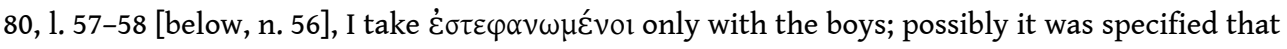
the boys wear wreaths because it was up to some adult to make certain that they did so: cf. LSAM 69 [= I.Stratonikeia II, 1, 1101], 1. 8-9). For the wearing of wreaths see also CHANIOTIS (2005), p. 5257, with references, especially p. 53 n. 40.

53. In addition to the instances cited below, n. 54, 56-57, see LSCG 71 (= IG VII, 351), 1. 10-12; LSS 14, 1. 33-37; LSAM 32 (= I.Magnesia, 98), 1.32-40; LSAM 81, 1. 6-13; IGR IV, 292, 1. 43-45; OGIS 11, 1. 21; IG XII 4, 1, 79, B, 1. 20-30; IG XII 4, 1, 291, 1. 7-12; IG XII 4, 1, 298, A, 1. 19-20; IG XII 4, 1, 330 (= LSCG 163), 1. 4-8. See also CHANIOTIS (1995), p. 157 with n. 77.

54. Lindos: LSS 85, 1. 32-36; Actium: LSS 45, 1. 41. As Stefano Caneva points out to me, at Sicyon the position of the boule-members - after the priest, musicians, and the gymnasiach, boys, and ephebes, and ahead only of the ordinary citizens - is unexpected: civic officials would normally march in front with the priest(s). It would appear either that Plutarch for some reason dislodged the councilors from their rightful place in the hierarchy or that this procession was exceptional.

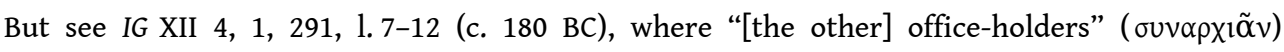
evidently come last in a parade, following other, specified officials and the gymnasiarch and youths (see the commentary in IG XII 4, 1, 291 ad loc.).

55. Thus the inclusion of the entire boule in the procession at Sicyon may be seen as an especial honor: for Aratus (if, to paraphrase Polyb., VIII, 12, 8, the dead have any sentience beyond the grave), for his family, and for the boule-members themselves. Conversely, the limitation of participation to the prytany-members may have had a practical end, to limit the number of mouths to feed following the sacrifice: cf. PAUL (2018), p. 329-331.

56. Antioch: LSAM 81, 1. 7-8. Delphi: LSCG 81, 1. 7-8; LSCG 80, 1. 56-59; LSS 44, 1. 8-11; LAUM (1914), nos. 27-29 (vol. II, p. 25-36); texts with French translations now in Choix - Delphes, nos. 137 (p. 250-251) and 167-168 (p. 301-307); see also HARRIs (2015), p. 72-75.

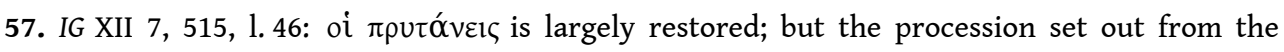
prytaneion (1.45-47), and the prytany-members played a particularly important role in the festival and its organization (1. 9, 40-41, 81, 103-104), so the restoration is virtually certain.

58. Delphi: LSCG 81, 1. 4-8 (see above, § 2.5, with n. 56); Pergamum: I.Pergamon I, 246 (= OGIS 332), 1. 33-40; Eretria: LSCG 92 (= IG XII 9, 189), 1.37-38. For private citizens in parades see also LSS 46, 1. 6-10; OGIS 11, 1. 21-22; SEYRIG (1929), no. I (p. 85-86), 1. 26-27. For the requirement to provide animals for sacrifice see PAUL (2018), p. 327-328 and 330-331.

59. E.g. LSCG 69, 1. 30-31; LSCG 92 (= IG XII 9, 189), 1. 32-33 and 38; LSCG 93, 1. 3-5; LSCG 163 (= IG XII

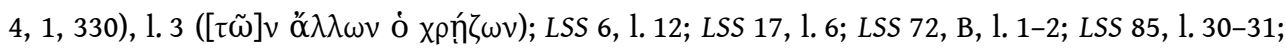

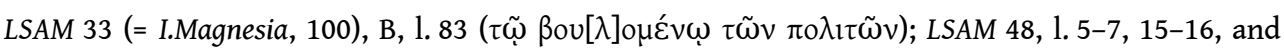
18-19; NGSL 7, 1. 4; NGSL 14, B, 1.58 and 107 (but B, 1. 92: plural); NGSL 24, 1. 3; I.Lampsakos, 9, 1. 32; SEG $44,505,1.5$ and [7].

60. For the site see PAPACHATZIS (1976), p. 88-109; GRIFFIN (1982), p. 6-15; LOLOS (2011), p. 279-282 and 377-384; LOLOS - GOURLEY (2011), p. 94-136. Moving of the city: Strabo, VIII, 6, 25; Diod. Sic., XX, 102, 2-4; Plut., Demetr., 25, 3; Paus., II, 7, 1; SKALET (1928), p. 80-82; HABICHT (1970), p. 74-75; PAPACHATZIS (1976), p. 93-94 n. 4; GRIFFIN (1982), p. 78-79; LESCHHORN (1984), p. 258-259; MALKIN (1987), p. 233-234; LOLOS (2011), p. 72-73 and 183-184; LOLOS - GOURLEY (2011), p. 94-96. Grid: ibid., p. 103-124 with p. 106 fig. 21; p. 128-134 with p. 135 fig. 50. 
61. Paus., II, 7, 5-8, 1 and 9, 6-11, 2; GRIFFIN (1982), p. 15-23; LOLOS (2011), p. 412-414.

62. For the bouleuterion at Sicyon see MCDONALD (1943), p. 240-244, and GNEISZ (1990), p. 351-352, both with references to the excavation reports; see also ROUX (1958), p. 149-152; PAPACHATZIS (1976), p. 105 n. 6; GRIFFIN (1982), p. 11-12; LOLOS (2011), p. 281; LOLOS - GOURLEY (2011), p. 124. It is tempting to suggest that the marchers would line up in the South Stoa, which extends perpendicularly (for over 100 meters) from the bouleuterion to the east (ibid., p. 124 with p. 94 fig. 6, 125 fig. 43, and 127 fig. 46). In any case, every procession would need to line up in order and to have adequate space to do so, though this is not something that is addressed in any inscription, so far as I am aware.

63. Just as it appears that the the prytany-members marched in processions more often than the entire boule (above, $\$ 2.5$, with n. 55-57), so the epigraphical evidence suggests that the prytaneion served as a departure point more often than the bouleuterion. A parade of orgeones of Bendis went from the hearth of the prytaneion in Athens to Bendis's sanctuary in Piraeus (LSCG 46 [= IG II ${ }^{2}$, 1283], 1.6-7; cf. 1.15). On Cos processions seem to have departed from the prytaneion quite frequently (IG XII 4, 1, 79, 1. 25-30; IG XII 4, 1, 291, 1. 7-12; IG XII 4, 1, 339, B, 1. 12-19). We also find processions leaving from the prytaneion on Lesbos (IG XII 2, 507, 1. 12-13; LSCG 128 [= IG XII Suppl., 29], 1.3), at Pergamum (I.Pergamon I, 246 [= OGIS 332], 1.14-17; IGR IV, 292, 1. 42-45), and on Amorgos (IG XII 7, 515, 1. 45-47).

64. Antioch: LSAM 81, 1. 7. Magnesia: LSAM 33 [= I.Magnesia, 100], A, 1. 38-41; for this inscription see DUNAND (1978); CHANIOTIS (2013), p. 37-38; PAUL (2018), p. 321. The officials are to assemble before the bouleuterion to hear a proclamation of the sacred herald (calling on the Magnesians to sacrifice and pray individually); but it seems improbable that they would don such festive attire solely for this. So, though it is hard to tell from this incomplete and somewhat disjointed decree, it is reasonable to suppose that they would also take part, thus clad, in the procession and sacrifice mentioned in A, 1. 33-34 (cf. B, 1. 16). With KÖHLER (1996), p. 51 n. 166, I do not think that the pompe can be identified with the exodos of the women, 1. 26-27, as DUNAND (1978), p. 203-204, would have it.

65. LSCG 92 (= IG XII 9, 189), 1.35-36. In LSAM 32 (= I.Magnesia, 98) a bull, purchased at an unspecified place (1.10-13), will be taken to the agora to be fattened for sacrifice (1.59-64). For departure from the marketplace see CHANIOTIS (1995), p. 156 with n. 73.

66. In the cult of Aleximachus, in a completely separate rite, a ram was boiled before the hero's statue, the meat of which would then serve as prizes for the athletic victors (IG XII 7, 515, 1. 7483). That the procession at Sicyon would end, and the sacrifice be performed, at the Arateion is improbable, at least if it set out from the bouleuterion. The Arateion was very near to the bouleuterion (Paus., II, 9, 6), so the priest would have reached the tomb before most of the processioners had even begun to move. This would be more or less true of a departure from anywhere in the agora (minimum dimensions: c. 214 by $174 \mathrm{~m}$; maximum: c. 282 by $208 \mathrm{~m}$; see LOLOS - GOURLEY [2011], p. 128). We would also expect a procession of such size and importance to pass through some of the residential portion of the city, in order to be seen. A large, open area would then be needed for the consumption of the sacrificial victims. I might add that the gymnasium at Sicyon had two fountain houses (GRIFFIN [1982], p. 13; PAPACHATZIs [1976], p. 102 fig. 95, p. 104 fig. 96, and p. 106-107 n. 1), which would provide an essential commodity for a large banquet (water was among the supplies for the banquet in honor of Aleximachus, along with oil, "service" for the meal, wine, and wood: IG XII 7, 515, 1. 58-59 and 65-68.

67. Paus., II, 10, 7 (cf. II, 10, 1); ROUX (1958), p. 149-152; DELORME (1960), p. 99-102 and pl. XI, fig. 20; PAPACHATZIS (1976), p. 106-107 n. 1; GRIFFIN (1982), p. 12-13; ANEZIRI - DAMASKOS (2004), p. 258 n. 80; MANGo (2004), p. 284-285 and 299; LOLOS (2011), p. 279-281; LOLOS, GOURLEY (2011), p. 125-126. The gymnasium lies only around 60 meters west of the bouleuterion, but it appears not to have communicated directly with the agora (ibid., p.126); and we can imagine the procession 
zigzagging through some of the city to the east and north before entering the gymnasium from its northern entrance. The question whether Pausanias saw one gymnasium or two does not concern me here; but see SKALET (1928), p. 25, and LOLOS (2011), p. 279-281 (two); ROUX (1958), p. 151-152, and PAPACHATZIS (1976), p. 106-107 n. 1 (one); DELORME (1960), p. 99-100 (undecided).

68. Amorgos: IG XII 7, 515, 1. 49-74. For dining in the gymnasium see DELORME (1960), p. 355-357 and Index (p. 528), s.v. "Banquet (dans les g.)"; sCHMITT PANTEL (1992), p. 323-324 and 367-371; MANGO (2004). For the contribution of animals by citizens see above, n. 58.

69. Syracuse: above, n. 29; Aigiale: IG XII 7, 515, 1.79-86. For the participation of the Technitai in competitions (their usual role) see ANEZIRI (2003), p. 267-289 and id. (2007).

70. LSCG 137, A, 1. 8; the same combination, in reverse order, in I.Knidos I, 59, 1. 16-17, and Plut. Arat., 45, 3. The trio is noted by CHANIOTIS (2013), p. 25, but without examples.

71. Memoirs (FGrHist IIB, 231): Arat., 3, 3; 32, 5; 33, 3; 38, 6. For the sources of the Aratus see GoLTZ (1883), p. 3-17; SCHULZ (1886), p. 29-57; WALBANK (1933), p. 15-19; KOSTER (1937), p. xiv-xvii and XXV-XXvi; PORTER (1937), p. Xiii-Xx; FLACELIÈRE - CHAMBRY (1966), p. 62-66.

72. Phylarchus and Polybius: Arat., 38, 11-12 (FGrHist IIA, 81 F 52; Polyb., II, 47-48); Myrsilus: Arat., 3, 5 (FGrHist IIIB, 477 F 13); Deinias: Arat., 29, 5 (FGrHist IIIB, 306 F 5); Polemon: Arat., 13, 2-5 (fr. 17, ed. PRELLER [1838]; all subsequent references are to Preller's edition of the fragments). In addition,

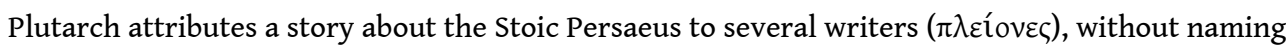
them (Arat., 23, 6).

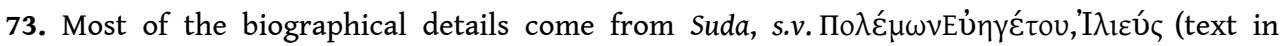
PRELLER [1838], p. 4; MÜLLER, FHG, p. 108), where Polemon is said to have lived during the reign of Ptolemy Epiphanes (205-180 BC) and to have been a contemporary of Aristophanes of Byzantium. Polemon is also listed in an inscription as a proxenos at Delphi for the year 177/6 BC (Syll. ${ }^{3}, 585$, 1. 265), the last we hear of him.

74. The fragments were first assembled by PRELLER (1838); MÜLLER, FHG III, p. 108-148, followed Preller's numbering, adding one fragment (76a); TRESP (1914), p. 85-90, 114-115, and 204-211, has the more substantial fragments pertaining to religion; and DEICHGRÄBER (1952) offers a fragmentby-fragment analysis. See more recently HUTTON (2005), p. 250-257. Quotation: W. Shakespeare, Twelfth Night, III, 3, 22-24 ("I pray you, let us satisfy our eyes/ With the memorials and the things of fame/ That do renown this city.").

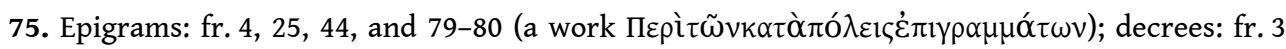

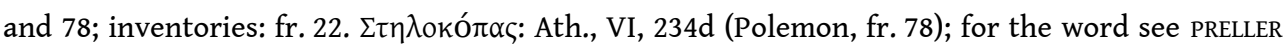

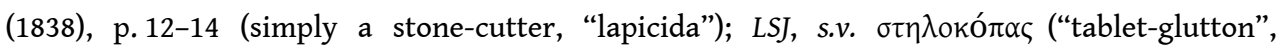

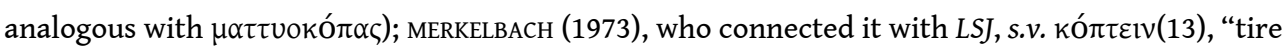
out, weary".

76. Ath., VI, 234d (Polemon, fr. 78). According to the Suda (above, n. 73), Polemon was granted Athenian citizenship.

77. Paintings: On the Stoa Poikile in Sicyon (fr. 14-15) and On the Paintings in Sicyon (fr. 16-17), if these are not one and the same work under two different names. Other references to Sicyon: fr. 72 (though possibly a reference to a Sicyon in Boeotia: MÜLLER, FHG, p 135-136, ad loc.); fr. 81 (a river Kephissos); fr. 100 (on the saying "sillier than the Adonis of Praxilla"). The last fragment is not assigned to a particular work; possibly Polemon discussed the Sicyonian poetess in connection with a statue of her by Lycippus (Tatian, Oratio ad Graecos, 33).

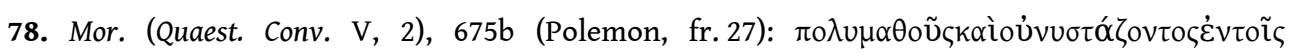

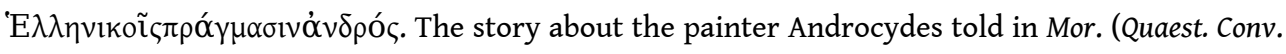
IV, 2, 3), 665d and (Quaest. Conv. IV , 4, 2), 668c seems also to derive from Polemon (fr. 66).

79. Arat., 13, 2-5 (Polemon, fr. 17). This whole section, or most of it, probably comes from Polemon (so PRELLER [1838], p. 47-48). After the citation of Polemon most of what follows is in 


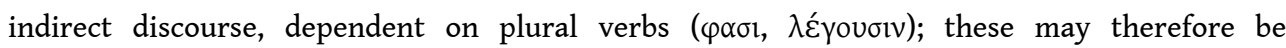
Polemon's, not Plutarch's, words.

80. Paintings to Ptolemy: Arat., 12, 6 and 13, 6. Epigram: Arat., 14, 3-4; this could also come from Aratus's Memoirs, but the proximity to the section on paintings may favor Polemon.

81. Arat., 32, 6; see GOLTZ (1883), p. 15; PORTER (1937), p. 69. Note that Plutarch says that the battle was expressively $(\dot{\varepsilon} \mu \varphi \alpha \nu \tau i \kappa \tilde{\omega} \varsigma)$ rendered by Timanthes; earlier (Arat., 13, 3) he called the painting of Aristratus and Nike worth seeing ( $\left.\dot{\alpha} \xi_{10} 0 \dot{\varepsilon} \alpha \tau o v\right)$. These would not seem to be Plutarch's own judgements. He had not seen the paintings in Sicyon, as all of the remaining paintings had been removed to Rome in the first century BC, to pay off the city's debts (Pliny, HN XXXV, 127; SKALET [1928], p. 21-22, 91, and 143; GRIFFIN [1982], p. 152). The possibility that he had seen either painting in Rome seems remote.

82. From a similarity between Plutarch's statement that the rites for Aratus had lapsed "from the passage of time and other factors" (Arat., 53, 7) and Diodorus's words about the demise of the cult of Demetrius at Sicyon (XX, 102, 3), НАВісHT (1970), p. 131 n. 4, concluded that the two passages had a common source. But I find it difficult to take these words as anyone's other than Plutarch's,

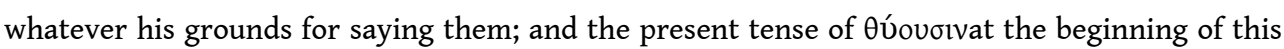
section (Arat., 53, 5), which is inconsistent with the later assertion of the ritual's decline, may betray a source contemporary with the festival, carelessly copied by Plutarch.

83. See SCHULTZ (1886), p. 54, whose only suggestion for a source for Aratus, 53 was a book on oracles and their interpretation.

84. So a quotation of the epitaph of the courtesan Lais is preceded by a tale of her murder in Aphrodite's sanctuary at the hands of jealous Thessalian women (fr. 44; the same story in Plut., Mor. [Amatorius, 21], 767f-768a, with some different details); see also fr. 25.

85. Residing in Sicyon only a few decades after the death of Aratus, Polemon was certainly in a better position than Plutarch to inquire and hear about its aftermath; but what he heard and what he chose to report would not necessarily be reliable as a consequence.

86. Fifteen years after the death of Aratus, in gratitude for a generous donation by Attalus I of Pergamum, the Sicyonians voted to erect a gold statue of Attalus and to establish annual sacrifices in his honor (Polyb., XVIII, 16, 3); and the Antigoneia, founded by Aratus for Antigonus Doson in the late 220s (Plut., Arat., 45, 3; Agis et Cleom., 37 [16], 7; cf. SEG 11, 338, 1. 12), were still being celebrated in Sicyon in the 160s BC: Polyb., XXVIII, 19, 3 and XXX, 29, 3; HАВICHT (1970), p. 80-81; PARKER (2004), p. 20, no. 15. Thus it is improbable that the festival of Aratus would have been abolished (or somehow allowed to lapse) already in the time of Polemon.

\section{ABSTRACTS}

At the end of his life of Aratus Plutarch recounts the death of the Achaean statesman in $213 \mathrm{BC}$, the subsequent transport of his body - after a consultation of the Delphic oracle - from Aigion to his native Sicyon, his burial inside of the city, and the annual festival established in his honor. Although Plutarch's account of the retrieval of the body is for several reasons highly suspect historically, his description of the festival rings true and appears to derive - not directly, I argue, but indirectly through an intermediate source - from an inscription. Most of the content and language finds close parallels in surviving inscriptions concerned with the conduct of sacrifices and, especially, with the large, organized processions that very often preceded them. I 
use material from these inscriptions to supplement and shed light on Plutarch's brief account and to offer a tentative reconstruction of the festival and its procession, in the context of what is known of the topography of Hellenistic Sicyon. I also make a suggestion, again tentative, of the identity of Plutarch's source for the passage.

À la fin de la Vie d'Aratos, Plutarque raconte la mort du chef d'État achéen en 213 av. n.è., le transfert de son corps - après consultation de l'oracle de Delphes - d'Aigion à Sicyone, sa cité d'origine, son inhumation à l'intérieur de la cité et la célébration annuelle établie en son honneur. Même si le récit de la récupération du corps n'est guère crédible d'un point de vue historique, la description de la fête par Plutarque sonne juste et semble dériver d'une inscription, par l'intermédiaire d'une autre source. Nombre d'aspects du contenu et du langage trouvent des parallèles étroits dans des inscriptions sur la tenue des sacrifices et, particulièrement, sur la description des grandes processions qui les précèdent souvent. Ces inscriptions permettent d'éclairer le bref compte rendu du Plutarque et d'offrir une hypothèse de reconstruction de la fête et de sa procession, dans le contexte de ce que l'on sait de la topographie de Sicyone à la période hellénistique. On tente également d'identifier la source de Plutarque pour ce passage.

\section{AUTHOR}

\section{DENNIS D. HUGHES}

Department of Classics

Grinnell College

Grinnell, Iowa

hughes@grinnell.edu 